\section{Aerosol climatology: on the discrimination of aerosol types over four AERONET sites}

D. G. Kaskaoutis ${ }^{1,2}$, H. D. Kambezidis ${ }^{1}$, N. Hatzianastassiou ${ }^{2}$, P. G. Kosmopoulos ${ }^{3}$, and K. V. S. Badarinath ${ }^{4}$

${ }^{1}$ Atmospheric Research Team, Institute for Environmental Research and Sustainable Development, National Observatory of Athens, Lofos Nymphon, P.O. Box 20048, 11810, Athens, Greece

${ }^{2}$ University of loannina, Department of Physics, Laboratory of Meteorology, 45110 Ioannina, Greece

${ }^{3}$ University of Athens, Department of Geology, University campus 15784, Athens Greece ${ }^{4}$ Forestry \& Ecology Division,National Remote Sensing Agency (Dept. of Space-Govt. of India) Balanagar, Hyderabad-500 037, India

Received: 14 March 2007 - Accepted: 24 April 2007 - Published: 11 May 2007

Correspondence to: D. G. Kaskaoutis (dkask@meteo.noa.gr)
Climatology of different aerosol

types

\section{ACPD}

D. G. Kaskaoutis et al.

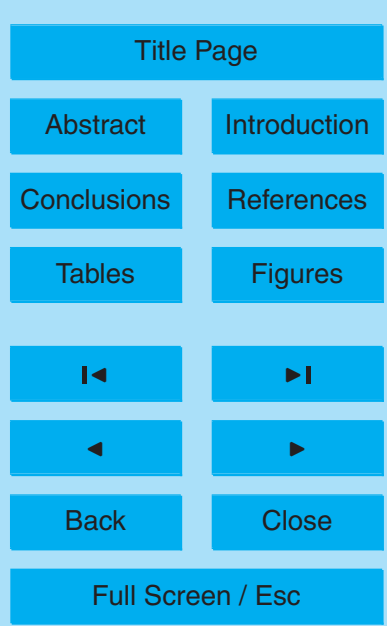

Printer-friendly Version

Interactive Discussion 


\section{Abstract}

Aerosols have a significant regional and global effect on climate, which is about equal in magnitude but opposite in sign to that of greenhouse gases. Nevertheless, the aerosol climatic effect changes strongly with space and time because of the large vari5 ability of aerosol physical and optical properties, which is due to the variety of their sources, which are natural, and anthropogenic, and their dependence on the prevailing meteorological and atmospheric conditions. Characterization of aerosol properties is of major importance for the assessment of their role for climate. In the present study, 3-year AErosol RObotic NETwork (AERONET) data from ground-based sunphotome10 ter measurements are used to establish climatologies of aerosol optical depth (AOD) and Ångström exponent $\alpha$ in several key locations of the world, characteristic of different atmospheric environments. Using daily mean values of $A O D$ at $500 \mathrm{~nm}\left(\mathrm{AOD}_{500}\right)$ and Ångström exponent at the pair of wavelengths 440 and $870 \mathrm{~nm}\left(\alpha_{440-870}\right)$, a discrimination of the different aerosol types occurring in each location is achieved. For 15 this discrimination, appropriate thresholds for $\mathrm{AOD}_{500}$ and $\alpha_{440-870}$ are applied. The discrimination of aerosol types in each location is made on an annual and seasonal basis. It is shown that a single aerosol type in a given location can exist only under specific conditions (e.g. intense forest fires or dust outbreaks), while the presence of well-mixed aerosols is the accustomed situation. Background clean aerosol conditions $\left(\mathrm{AOD}_{500}<0.06\right)$ are mostly found over remote oceanic surfaces occurring on average in $\sim 56.7 \%$ of total cases, while this situation is quite rare over land (occurrence of $3.8-13.7 \%$ ). Our analysis indicates that these percentages change significantly from season to season. The spectral dependence of AOD exhibits large differences between the examined locations, while it exhibits a strong annual cycle.
Climatology of different aerosol types

D. G. Kaskaoutis et al.

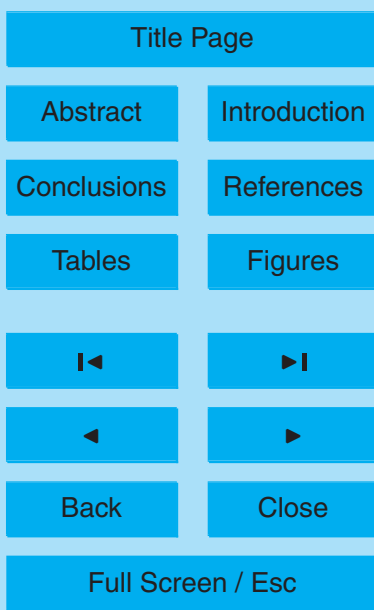

Printer-friendly Version

Interactive Discussion 


\section{Introduction}

Atmospheric aerosols play an important role in global and regional climate. They have through their direct and indirect effects a significant impact on solar radiation reaching the ground, the energy budget and precipitation formation and distribution (Haywood 5 and Boucher, 2000; IPCC, 2001). The climatic effect of aerosols is closely related to their physical properties and size, the surface albedo and the relative altitude between aerosol layers and clouds (Kinne and Pueschel, 2001; Abel et al., 2005). The various aerosol types have a different effect on the sign and magnitude of the aerosol radiative forcing (Satheesh and Krishna Moorthy, 2005). For example, the presence of absorberosols such as black carbon can change the sign of forcing from negative (cooling) to positive (heating) (Heintzenberg et al., 1997). They have played an important role for the climate of the Earth-atmosphere system, while recent studies have shown that aerosols can also affect atmospheric general circulation patterns (Kristánsson et al., 2005; Lau et al., 2006) and biochemical cycling (Xin et al., 2005). However, the 15 quantification of the aerosol effects is difficult and more complex than the quantification of radiative forcing by greenhouse gases because aerosol mass and particle number concentrations are highly variable in space and time, due to their much shorter atmospheric lifetime compared with the important greenhouse gases. Aerosol properties are difficult to measure without instrumental offsets or bias, making it difficult to estimate the aerosol radiative effects. Therefore, there is large uncertainty regarding the aerosol overall climatic effect (Granger Morgan et al., 2006; Remer and Kaufman, 2006; Yu et al., 2006). Better estimates of the aerosol radiative effects on a planetary scale are required to reduce the uncertainties. To achieve this, it is necessary a better characterization of aerosol physical and optical properties. Therefore, numerous studies have been undertaken to characterize the aerosol properties on a global scale. To this aim, both surface- and satellite-based techniques have been developed and they are extensively used for monitoring aerosol properties worldwide. Each technique has advantages and drawbacks. Aerosol measurements from satellites progressed
Climatology of different aerosol types

D. G. Kaskaoutis et al.

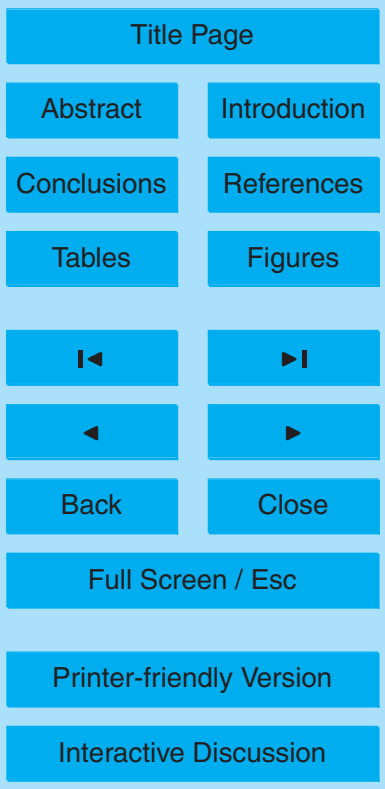


rapidly in the last few years, but there are still problems (e.g. Zhao et al., 2005). On the other hand, surface-based aerosol measurements have also progressed with the establishment of ground-based monitoring networks, especially with the development of the Aerosol Robotic Network (AERONET, Holben et al., 1998; 2001). These measure5 ments are very important since they are complemented with those of field campaigns (ground-based and airborne), for calibration and validation of satellite data.

At the global scale, the dominant aerosol types are biomass-burning particles from the extensive forest fires in Amazonia (Eck et al., 1998; Reid et al., 1999) and South Africa (Eck et al., 2001b, 2003), urban/industrial aerosols mainly over densely pop10 ulated areas of North America (Eck et al., 1999), Europe (Dubovik et al., 2002) and Southeastern Asia (Kim et al., 2004; Latha and Badarinath, 2005) and desert-dust particles originated from the arid areas of North Africa (Smirnov et al., 1998; Masmudi et al., 2003), Arabian peninsula (Smirnov et al., 2002a) and East Asia (Kinne and Pueschel, 2001; Ogunjobi et al., 2004). On the other hand, remote oceanic areas 15 are usually unaffected from continental aerosols and, therefore, present a clean background atmosphere mainly consisting of sea-salt and natural-sulfate particles (Smirnov et al., 2002b, 2003).

Biomass burning in the tropical broadleaf and cerrado forested regions of Brazil creates a smoky haze that covers much of the South American continent from August to September (Artaxo et al., 1994; Holben et al., 1996). After the end of the fire event particle coagulation, gas-to-particle conversion, heterogeneous reactions in hazes, and cloud processing, influence the size distribution of the particles causing a decrease in the Ångström exponent as the particles age (Reid et al., 1998).

The increase of pollution due to growing of population and density of industries has 25 a direct impact on climate conditions, especially the increase of haze, fog, and cloudy conditions (Mukai et al., 2006), which decrease the visibility especially under high turbidity conditions. Aerosols in urban areas regions are chemically and substantially different from aerosols in remote areas with the most obvious differences being the high concentrations of sulfur, black carbon and heavy metals in urban aerosols (Latha

\section{Climatology of different aerosol types}

D. G. Kaskaoutis et al.

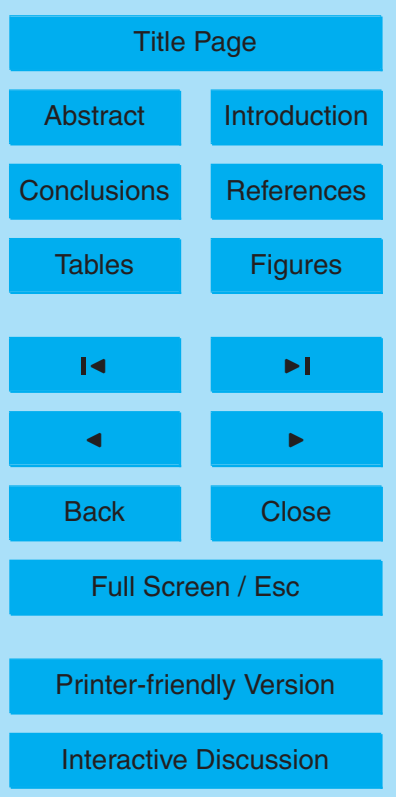

EGU 
and Badarinath, 2005). Nowadays, the characterization of aerosol properties in urban environments is important due to the rapid growth of both population and economy activities, with associated increases in fossil-fuel combustion, and the possible regional and global climatic impacts from aerosol emissions.

Mineral dust, which is a major component of natural aerosols, often has been neglected in anthropogenic climate change considerations (Andreae, 1996). Dust plays an important role in radiative processes and its optical properties are significant for various estimations of radiative forcing. Its influence on climate change is very important, but with considerable uncertainties (Claquin et al., 1998). Despite the long 10 history of dust aerosol studies our knowledge of dust optical properties is still far from being sufficient (Sokolik and Toon, 1999). They also showed that aerosol extinction, single scattering albedo, and the asymmetry parameter are very sensitive to the individual minerals and their mixtures in dust composition. Several extensive scientific experiments of dust aerosols were carried out, such as ACE-2 and ECLATS in Sahara, 15 HEIFE in Northwestern China, and the Mediterranean Israeli Dust Experiment (MEIDEX). Especially, the Saharan aerosol influence in Mediterranean Sea and continental Europe has extensively been monitored (Balis et al., 2004; Barnaba and Gobbi, 2004; Antoine and Nobileau, 2006; Pace et al., 2006).

The maritime aerosols can be divided into two groups (Satheesh and Krishna Moor-

thy, 2005): the say-spray, produced by the wave break to the coasts or by the strong winds and the natural sulfate particles released from the phytoplankton. In general, are coarse particles, especially the sea spray, with diameters above $0.8 \mu \mathrm{m}$ and constitute the main aerosol type in remote Ocean. Their physical and optical properties have extensively been monitored by Smirnov et al. (2002b, 2003).

25

Despite the general knowledge about aerosol properties over the world, there are still uncertainties and incomplete knowledge in many aspects. For example, the characterization of aerosols from space cannot still be considered to represent the truth, since although many problems related to satellite observations of aerosols have been resolved by more sophisticated instruments, there are still problems as shown by discrepancies

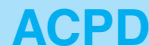

$7,6357-6411,2007$

Climatology of different aerosol types

D. G. Kaskaoutis et al.

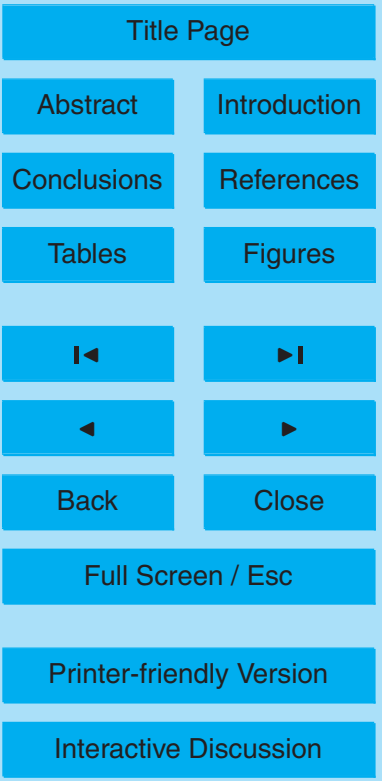

EGU 
between different satellite products (Zhao et al., 2005). On the other hand, surfacebased measurements are continuously growing. Especially, the AERONET monitoring network is expanding rapidly, encompassing nowadays more than 300 stations worldwide. Nevertheless, the majority of these stations was established only recently thus 5 not providing long-term data. This is a problem since the aerosol properties change with time. The selection of AERONET stations is made based upon their location, in order to assure the most complete possible coverage of the different climatic types of the globe.

The present study examines the aerosol optical properties over selected locations 10 worldwide. The aerosol properties are key parameters for the determination of aerosol climatic effects (e.g. Hatzianastassiou et al., 2004). The selection of the stations in this study is made with the criterion of the ability that they represent the major different climatic types of the world and the availability of reasonably complete time-series of data (2002-2004). The data of aerosol optical properties were obtained from the AERONET 15 homepage, http://aeronet.gsfc.nasa.gov/, in the form of daily-mean values. The characterization and subsequent discrimination of different aerosol types (biomass-burning, urban/industrial, clean maritime and desert dust) is achieved by establishing and applying a methodology based on the wavelength dependence of the aerosol optical depth (AOD) and the Ångström exponent $\alpha$. A similar study, but using different aerosol properties, i.e. aerosol single scattering albedo, size distribution and asymmetry factor, in key worldwide locations has been published by Dubovik et al. (2002). In this study, we allow the characterization of aerosol properties for each location and season, permitting thus the establishment of an aerosol climatology, which is possibly also representative for the greater surrounding regions. The study aims at showing the large variability in terms of aerosol optical properties between different key locations over the globe, and hence the strong contrasts between their climatic effects. In Sect. 2 we describe the data used and the selected geographical locations, while in Sect. 3 the analysis and applied methodology are presented. In Sect. 3 we discuss the obtained results, and finally draw conclusions in Sect. 4.

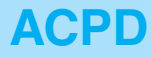

$7,6357-6411,2007$

Climatology of different aerosol types

D. G. Kaskaoutis et al.

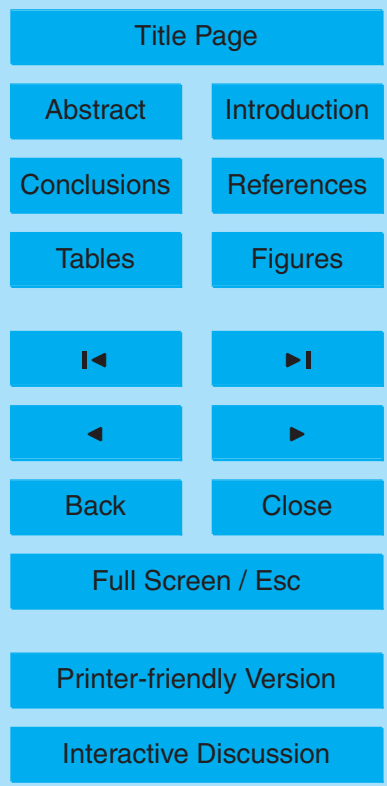

EGU 


\section{Study regions and data used}

\subsection{Regions of study}

We have selected four AERONET stations located in regions which are representative of the four major aerosol regimes (or environments), i.e. biomass-burning, urban, mar5 itime and desert. The four stations (see Fig. 1) are: a) Alta Floresta (Brazil), a rural site directly influenced by smoke produced by biomass burning during the fire season, $b$ ) Ispra (Italy), an urban/industrial area with significant anthropogenic and industrial activities, c) Nauru, a remote island in the tropical Pacific characterized by very low aerosol loading, and d) Solar Village (Saudi Arabia), a continental remote site with significant 10 contribution of desert particles. The AERONET data are provided in three categories: cloud contaminated (level 1.0), cloud-screened (level 1.5) following the methodology described by Smirnov et al. (2000b), and cloud-screened and quality-assured (level 2.0), which was used in the present study. The selection of the stations was made based upon the criterion of the availability of enough (3-year) cloud-screened (Smirnov et al., 2000b) and quality-assured (level 2.0) aerosol data.

The AERONET site of Alta Floresta is located in the tropical forested region of Amazonia and is characterized by agricultural activities and biomass burning. Therefore, this site is representative of nearly maximum aerosol loading levels in the biomassburning regions within the Amazon basin. It is characterized by low cloud fraction (Ar20 taxo et al., 1994) especially in the Amazonian dry season (August-September), when the majority of aerosol data were collected. Reduction in surface incident solar radiation results in the heating of the lower troposphere thereby decreasing local cloud cover, an effect that Hansen et al. (1997) called the "semi-direct" aerosol radiative forcing effect. The Alta Floresta site in the south central Amazon basin is frequently affected by smoke during the biomass-burning season and it is fairly typical among other sites dominated by heavy smoke in the Amazon Basin (Artaxo et al., 1994). In addition to strong local sources, smoke is advected over Alta Floresta originating over a $2500-\mathrm{km}$ fetch. Therefore, the aerosols over the site are composed of both local and

\section{Climatology of different aerosol types}

D. G. Kaskaoutis et al.

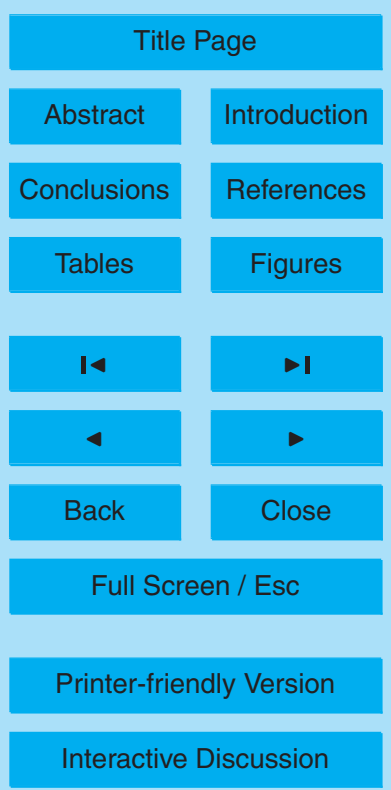

EGU 
well-aged smoke particles (Reid et al., 1999).

Ispra is an urban/industrial area in North Italy and it is characteristic of continental climate. The predominant aerosols are of local origin (anthropogenic activities), while mixed-type aerosols can occur during periods of significant Saharan outflows, which

5 can affect this region especially in spring and summer (Barnaba and Gobbi, 2004; Antoine and Nobileau, 2006). Monthly variability of the AOD over Ispra has been investigated by Hauser et al. (2005) using AERONET, MODIS and AVHRR data, while the diurnal AOD variability was investigated by Smirnov et al. (2002c).

The isolated island of Nauru is situated in the tropical western Pacific Ocean. The 10 island is very small with a total land area of about $25 \mathrm{~km}^{2}$. It lies $\sim 40 \mathrm{~km}$ south of the equator and the nearest island is $300 \mathrm{~km}$ away. Nauru is a good example of an equatorial oceanic site and was chosen by the Atmospheric Radiation Measurement (ARM) Program to set up a Cloud and Radiation Testbed site (Mather et al., 1998). This site was selected because it can be assumed representative of clean background 15 conditions, since it is usually unaffected by long-range transport of pollutants like other remote sites in the Atlantic Ocean (Smirnov et al., 2002b). Previous results regarding aerosol climatologies over Nauru can be found in the works by Smirnov et al. (2002b, c, 2003).

A lot of studies have been conducted for desert aerosols in the Saharan and Gobi deserts, but rather few for the Arabian Peninsula, which also constitutes one of the major world sources of desert particles. Smirnov et al. (2002a) investigated the aerosol properties over the Persian Gulf, while Otterman et al. (1982) based on Landsat data derived characteristics of desert aerosols in the Persian Gulf. Ground-based or airborne data were acquired mainly in the spring or summer of 1991 (Hobbs and

25 Radke, 1992) and they have focused on the production of smoke from Kuwait oil fires. Desert aerosols have not been extensively studied in the continental Arabian Peninsula. Therefore, we have selected in the present study the AERONET Solar Village as representative of desert aerosols. This site is located in the middle of the Arabian Peninsula, far away from the Persian Gulf or other industrialized areas. The remote-

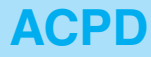

$7,6357-6411,2007$

Climatology of different aerosol types

D. G. Kaskaoutis et al.

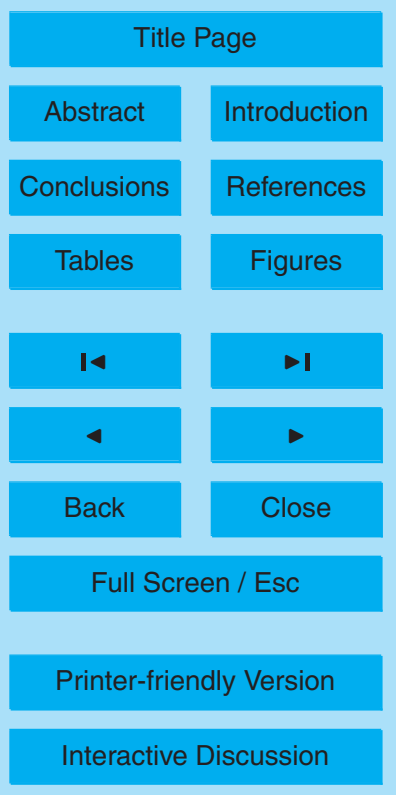


ness of the area favors to study the optical properties of desert dust aerosols, since the dust outbreaks are common especially in the spring period. The only existing study using data from Sollar Village is that by Smirnov et al. (2002c) who investigated the diurnal variation of AOD.

\section{$5 \quad 2.2$ Instrumentation and aerosol data}

The measurements reported in this work were made with the CIMEL sunphotometers (CE-318), which are automatic sun-sky scanning spectral radiometers. A very brief description is given here since a large number of studies describe the instrumentation, data acquisition, retrieval algorithms and calibration procedures which conform to the standards of the AERONET global network, as well as the uncertainty of final released products and the applied cloud-screening procedures (Holben et al., 1998, 2001; Eck et al., 1999; Smirnov et al., 2000b). The CIMEL radiometer takes measurements of the direct sun and diffuse sky radiances every 15 minutes within the spectral range 340$1020 \mathrm{~nm}$ and $440-1020 \mathrm{~nm}$, respectively. The direct sun measurements are performed in eight spectral channels: $340,380,440,500,675,870,940$ and $1020 \mathrm{~nm}$. Seven of the eight bands are used to acquire AOD, while that at $940 \mathrm{~nm}$ is used to estimate total precipitable water content. The Ångström parameter is usually computed from AOD at 440 and $870 \mathrm{~nm}$, but it can be also computed at any other pair of wavelengths (e.g. $380 \mathrm{~nm}-440 \mathrm{~nm}$ or $675 \mathrm{~nm}-870 \mathrm{~nm}$ ). Sky radiance almucantar measurements in 20 conjunction with direct Sun measurements of AOT at 440, 675, 870 and $1020 \mathrm{~nm}$ are also used to retrieve aerosol columnar size distributions (from 0.05 to $15 \mu \mathrm{m}$ ), single scattering albedo, and refractive indices Dubovik and King (2000). The filters utilized in these instruments are ion assisted deposition interference filters with a FWHM of $10 \mathrm{~nm}$ except for the 340-nm and 380-nm filters having a FWHM of 2 and $4 \mathrm{~nm}$, respectively. Calibration of field instruments is performed by a transfer of calibration from reference instruments, which were calibrated by the Langley plot technique at Mauna Loa Observatory, Hawaii. The intercalibration of field instruments is performed both predeployement and postdevelopment at Goddard Space Flight Center (GFSC), and

\section{Climatology of different aerosol types}

D. G. Kaskaoutis et al.

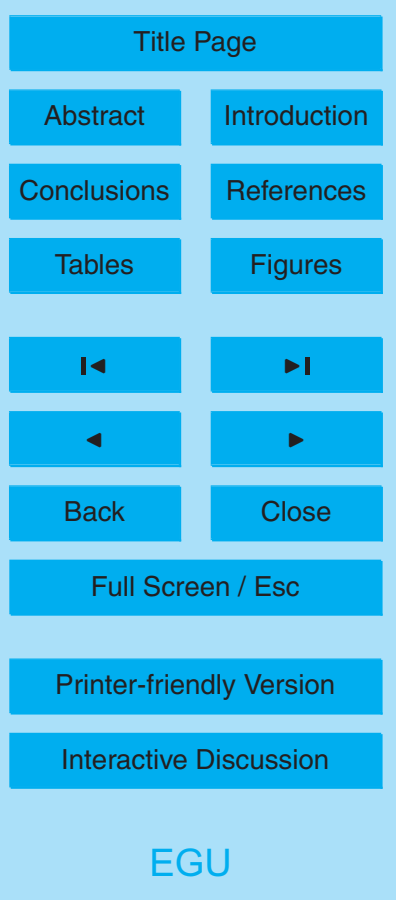


a linear change in calibration with time was assumed in the interpolation between the two calibrations. Typically, the total uncertainty in $\mathrm{AOD}_{\lambda}$ for a field instrument lies between about \pm 0.01 to \pm 0.02 (under cloud-free conditions, is \pm 0.01 for $\lambda>440 \mathrm{~nm}$, and \pm 0.02 for shorter wavelengths), and is spectrally dependent with the higher errors in the 5 UV band. The CIMEL instruments are not temperature stabilized. Applying the spectral temperature sensitivity of the instrument to the measurements in a temperaturecontrolled chamber showed agreement with the manufacturers published temperature sensitivity of the detectors. However, the $1020 \mathrm{~nm}$ channels showed significant voltage temperature variation $\left(0.25 \pm 0.05 \%{ }^{\circ} \mathrm{C}\right)$ warranting a correction to a reference temper10 ature (Holben et al., 1998; Smirnov et al., 1998).

In this study, level 2.0 AERONET data are used; specifically, we analyze daily mean values of spectral AOT and Ångström parameter of aerosol particles. The period of measurements along with the total number of daily values for each of the four locations, and its seasonal variation, are all presented in Table 1. The largest number of 5 data (792) is for the Solar Village station, probably because of the stable and sunny weather conditions in this site, permitting continuous measurements over long periods, especially in spring and summer. Taking into account all the calibration and instrumental problems, the accuracy of aerosol optical depth data employed in this study is within $\sim \pm 0.02$. Given that sun-photometer measurements can be made only for meteorological conditions involving low-cloud cover or conditions in which the sun is visible through cloud gaps, the measurements are naturally biased towards atmospheric high-pressure systems. Therefore, there are relatively few measurements taken in Alta Floresta and Ispra during cloudy and rainy periods (winter), when maximum rainfall and cloud cover occur. It is likely that ground-level in-situ sampling done on rainy days would record lower aerosol concentrations due to washout and wet deposition of aerosols, as this may result in lower seasonal mean concentrations during months of higher rainfall. Rapid-filter degradation in the harsh environmental conditions of Nauru (sea salt, dust mixture and high humidity) was a problem during the measurement period and for this reason these data are fewer (total number of 363 ) than those from the

\section{Climatology of different aerosol types}

D. G. Kaskaoutis et al.

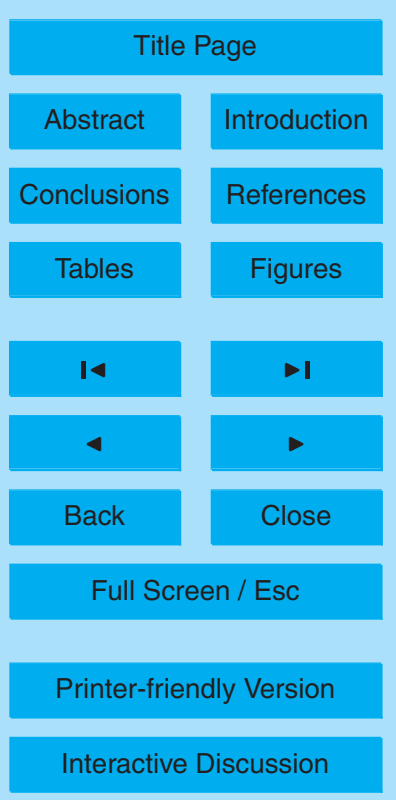

EGU 
rest of selected locations. Despite the differences in the total number of daily mean values between the four stations, care has been taken to ensure the representativity of the seasonal variation of aerosol properties (AOD and Ångström exponent) through the existence of a minimum number of data in each season (percentages ranging from 516 to $36 \%$ of the total number of data, see Table 1 ).

\section{Results and discussion}

\subsection{Annual cycle of spectral AOD values}

The aerosol optical depth is a strong function, of wavelength $(\lambda)$. The spectral nature of $\mathrm{AOD}_{\lambda}$ is determined by the aerosol sources, air masses, prevailing meteorological conditions and mixing processes in the atmosphere, while it is affected by both natural (e.g. fires, dust outbreaks, sea spray and natural-sulfate emissions) and anthropogenic processes, as well as aging processes (Schuster et al., 2006). Therefore, we relied on spectral aerosol optical depth $\left(A O D_{\lambda}\right)$ data to investigate the variability of aerosol properties and possibly derive regional climatologies for the four selected locations. 15 Figure 2 displays the monthly variation of $\mathrm{AOD}_{\lambda}$ at three different wavelengths for each site. We have chosen to use spectral values at 380,500 and $870 \mathrm{~nm}$ to cover the solar spectrum for which aerosol properties are most relevant The computed mean annual values of $\mathrm{AOD}_{500}$ and $\alpha_{440-870,}$ over the whole period 2002-2004, are also given.

In Alta Floresta (Fig. 2a), a typical biomass burning area, the smoke AOD values dra-

matically increase during the biomass-burning season, i.e. in late summer and autumn months, against clean background conditions in the rest of the year. This strong seasonal variation of AOD is in agreement with Duncan et al. (2003) reporting that biomass burning in Amazonia exhibits inter-annual and seasonal variations. Note that there are large differences in the rate of increase of AOD values at different wavelengths in the biomass-burning season. Thus, the AOD at 380 (blue curve) increases by a factor of 9.8 from June to September compared to 7.1 for AOD at $870 \mathrm{~nm}$ (red curve). This is

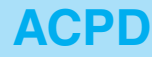

$7,6357-6411,2007$

\section{Climatology of different aerosol types}

D. G. Kaskaoutis et al.

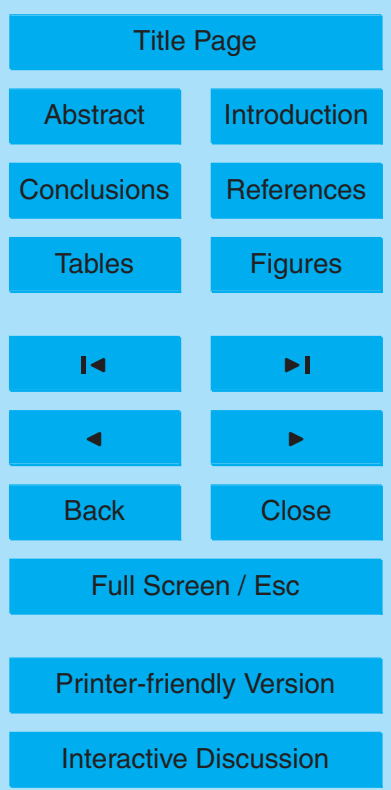

EGU 
due to the strong presence of fine biomass-burning aerosols, having a greater effect on the AOD in the ultraviolet (UV) than in the near infrared wavelengths (e.g. Schuster et al., 2006). The high $A O D_{500}$ values during the biomass-burning months are in agreement with those reported by Reid et al. (1999) and the Smoke, Clouds, and 5 Radiation-Brazil (SCAR-B) experiment conducted in Central Brazil. Our results for Alta Floresta agree well with those given by Holben et al. (1996) who reported averaged AOD values at $440 \mathrm{~nm}$ ranging from $\sim 1.0$ to 1.5 during biomass burning in Amazonia, versus background AOD values of about 0.2 at $440 \mathrm{~nm}$, results. Nevertheless, the computed values of $A O D_{500}$ seem to be smaller than those reported by Eck et al. (2001b, 10 2003) for African savanna fires, ranging from a minimum of $\sim 0.2$ to a maximum of $\sim 2.1$ at $440 \mathrm{~nm}$.

The large AOD values in Ispra (Fig. 2b) during local spring (March-May) and secondarily in summer (June-August), especially at the shorter wavelengths, are attributed to the increased loading of smaller-size continental aerosols produced by industrial 15 and anthropogenic activities as well as (during summer) to the secondary submicron aerosols produced by photochemical reactions. The role of fine aerosols is indicated by the fact that the largest $A O D_{380}$ value occurs in June, while the largest $A O D_{870}$ one in April. Note that the decrease of spectral AOD values is larger in summer than spring; thus the ratio $A O D_{380} / A O D_{870}$ is equal to 3.8 in summer (June) against 2.4 in spring 20 (April). This is due to the presence of coarse, probably dust or well-mixed aerosols in spring over Ispra, Indeed, different studies have indicated significant contributions by mixed aerosols in spring. Thus, Barnaba and Gobbi (2004) and Antoine and Nobileau (2006) confirmed strong Saharan dust outbreaks in late spring. Our mean $A O D_{500}$ value (0.34) compares well with the corresponding previous values reported for the

25 same site by Hauser et al. (2005) and Smirnov et al. (2002c), whereas it is generally larger than corresponding $\mathrm{AOD}_{500}$ values for other urban areas (e.g. GSFC, Buenos Aires, Mexico City etc.) (Dubovik et al., 2002; Smirnov et al., 2002c).

Over Nauru (Fig. 2c), a pristine oceanic region, there is not a simple annual cycle. In general, the values do not exceed 0.16 , i.e. a value that corresponds to clean

\section{Climatology of different aerosol types}

D. G. Kaskaoutis et al.

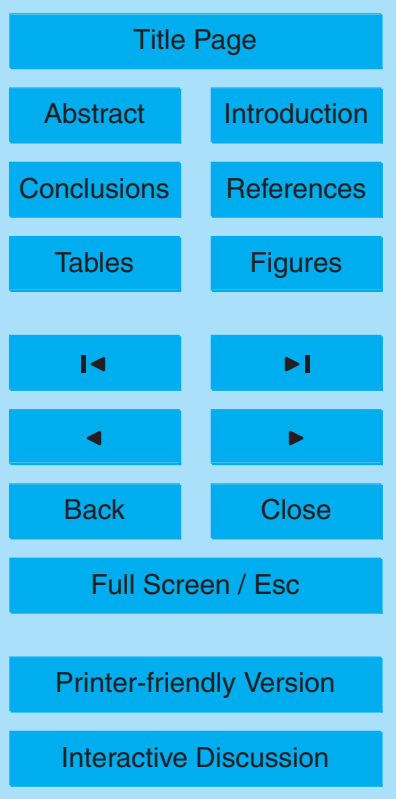


background conditions for the rest of examined sites. Moreover, the high AOD values around September may not be fully representative because of the small number of data (15 daily means in September 2002-2003). This can be crucial since several studies (e.g. Ramachandran et al., 2004) have shown that aerosol mass, number con5 centrations, optical depths and scattering coefficients at different marine locations are strongly dependent on surface wind speed. This is especially valid for the coarse mode particles, which are most probably produced by sea-spray and blown dust) whereas the fine mode particles are most probably produced by gas-to-particle conversion and subsequent coagulation (Smirnov et al., 2002b, 2003). Note that in local spring and sum10 mer months (March to June) the AOD is larger at $870 \mathrm{~nm}$ than at $675 \mathrm{~nm}$, implying thus negative $\alpha_{675-870}$ values in this spectral region (not shown here). Such negative values, indicative of coarse particles, have been also indicated by Adeyewa and Balogun (2003) for Abisco, Sweden and Cachorro et al. (2001) for Central Spain . In Sect. 3.3 it will be shown that these AOD values are caused mainly by dust aerosols in these 15 seasons. Our $\mathrm{AOD}_{500}$ values in Nauru compare well with those reported by Smirnov et al. (2002b) for the same site, indicating also the absence of a strong seasonal cycle.

The AERONET station of Solar Village exhibits a clear annual cycle of AOD with a significant increase in late spring towards values near 0.5 (Fig. 2d). This increase is attributed to large concentrations of coarse-mode aerosols (desert dust), as indicated by the slightly larger increase in AODs at the longer wavelengths, from background levels in January to turbid conditions in May. More specifically, the $A O D_{380}$ increases from January to May by a factor of 2.8, against a corresponding increase of 3.4 for $\mathrm{AOD}_{870}$. Our results are in agreement with those reported by Smirnov et al. (2002a) reporting the highest $\mathrm{AOD}$ and the lowest $\alpha_{440-870}$ values in Bahrain during spring. The production of dust during this season is favored by increased wind speeds as reported by Liu et al. (2000) and Smirnov et al. (2002a).

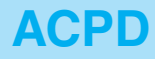

$7,6357-6411,2007$

\section{Climatology of different aerosol types}

D. G. Kaskaoutis et al.

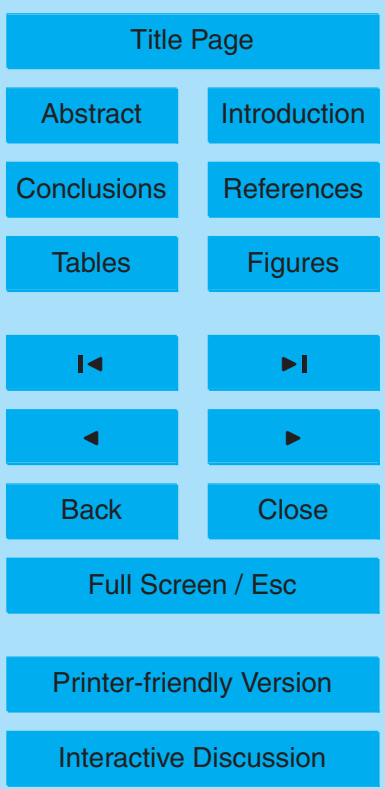




\subsection{Spectral variation of aerosol optical depth}

The spectral variation of AOD is important for modeling the radiative effects of aerosols (e.g. Hatzianastassiou et al., 2006), correcting for the aerosol effects in remote sensing applications and identifying the aerosol source regions and the temporal evolution

5 of aerosols (e.g. Masmudi et al., 2003). It is also important in both interpolating and extrapolating AOD beyond measured values for use in flux and energy balance computations, as well as for obtaining aerosol size distribution (e.g. D' Almeida, 1987; Fouquart et al., 1987). In addition, the Ångström exponent allows estimation of key aerosol optical parameters (Reid et al., 1999). Many studies on spectral variation of 10 AOD (e.g. Holben et al., 1991; Kaufman et al., 1992; O' Neill and Royer, 1993; O' Neill et al., 2001) rely on the Ångström exponent, $\alpha$, which quantifies this spectral dependence (Ångström, 1929). The wavelength dependence of AOD depends primarily on the aerosol scattering efficiency and, to a much lesser extent, on the aerosol absorption characteristics (Collaud Coen et al., 2004).

15 In Fig. 3, the spectral variation of annual mean AOD values is given for each location. The red curves refer to 2002, blue ones to 2003 and green lines to 2004 . No clear indications on possible inter-annual trends can be derived from Fig. 3. The mean annual AOD values in Alta Floresta are greatest in 2002 and lowest in 2003, while in Ispra they are of similar magnitude for the same two years. In Nauru, the highest AODs are depicted in 2004, while in Solar Village in 2003. The corresponding annual mean $\alpha$ values are also shown in Fig. 3 for every year. Obviously, the wavelength dependence of AOD is similar between Alta Floresta and Ispra, with $\alpha$ values ranging from about 1.3 to 1.6. For both locations, the steep decrease towards larger wavelengths indicates the strong presence of fine-mode particles. On the contrary, the spectral decrease of AOD is smoother for Nauru and Solar Village ( $\alpha$ values ranging between about 0.3 and 0.55 ) indicating the significant presence of coarse particles, on a global mean basis. In general, there are small inter-annual differences in terms of the spectral dependence of $A O D$, which is also indicated by the rather similar annual

\section{Climatology of different aerosol types}

D. G. Kaskaoutis et al.

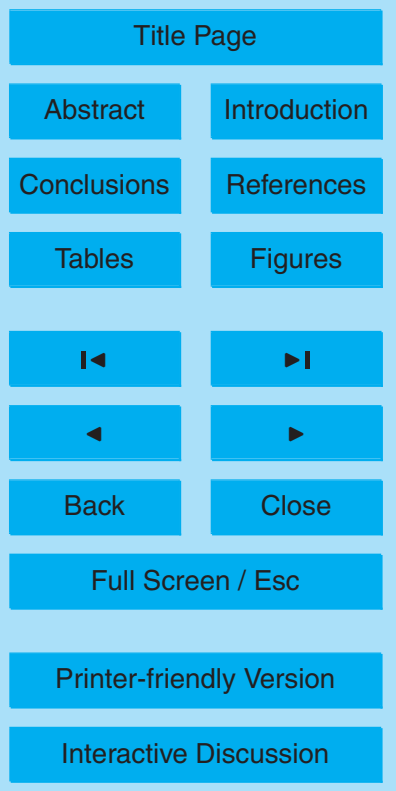


mean $\alpha$ values. Only in Nauru, there is a different pattern, not exhibiting the continuous decrease of AOD with increasing wavelength as in the rest of examined sites. Furthermore, there are inter-annual differences in terms of both AOD values and their spectral dependence. In contrast to the other sites, the AOD values slightly increase in 5 the near-infrared (near-IR) wavelengths, implying thus negative $\alpha$ values. The spectral dependence of the AOD is mainly driven by the scattering efficiency, which is related to the aerosol size distribution. Therefore, the fine-mode particles (biomass smoke and urban aerosols) exhibit a clearly wavelength dependent scattering more pronounced at shorter wavelengths, while the scattering due to coarse particles (sea-salt and desert 10 dust) is weakly dependent on wavelength. This was clearly established by Schuster et al. (2006) through Mie calculations.

Beyond examining the spectral dependence of AOD on an annual mean basis, more information can be obtained by doing so on a seasonal or even better on a monthly basis. Thus, Fig. 4 provides the spectral dependence of monthly values of AOD for each selected site. In Alta Floresta (Fig. 4a), the spectrally resolved AOD exhibits a large variability from month to month, especially at the shorter wavelengths (values of $\mathrm{AOD}_{380}$ ranging from about 0.1 to 1.8 ). Moreover, the spectral dependence of AOD is extremely large in August and September due to the intense forest fires taking place (see Sect. 3.1) and the strong presence of fine aerosols. As suggested by Reid et al. (1999) the fine-mode particles cause about three-times larger increases in AODs at shorter wavelengths, while the coarse-mode particles cause almost identical increases at both smaller and larger wavelengths. The results of Fig. 4a are in line with those of Fig. 2a, indicating $A O D_{1020}$ values which are larger in September than March by $\sim 4$ times, while those of $A O D_{340}$ are larger by $\sim 11$. Note that in the period from January to May the spectral variation of AOD is small, indicating the presence of coarse aerosols in the region. These particles should be maritime or dust and can stand as mixtures with fine particles. Over the period in term, the values of $\alpha$ vary between 0.92 and 1.27 , i.e. below the annual mean values (1.32-1.5, see Fig. $2 \mathrm{a})$.

In Ispra (Fig. 4b) the AOD wavelength dependence does not exhibit a significant

\section{Climatology of different aerosol types}

D. G. Kaskaoutis et al.

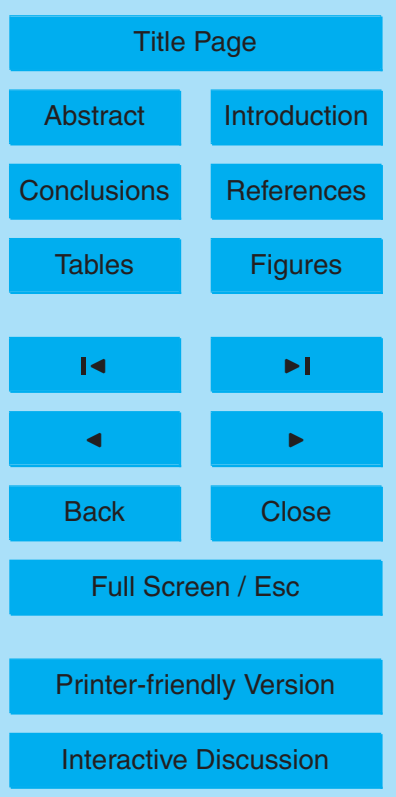

EGU 
monthly variability as that in Alta Floresta. Nevertheless, it shows a weaker wavelength dependence during spring (March-May) with $\alpha$ values near 1.3. In addition, March and April exhibit the highest AOD values at the larger wavelengths, indicating thus a contribution by coarse-mode particles. On the contrary, in local summer (June-August), but 5 also in November, the spectral decrease of AOD with increasing wavelength is steeper, indicating a strong contribution by fine-mode aerosols. These aerosols originate from the strong anthropogenic activity in the industrialized areas of North Italy, and their accumulation in summer is favored by the stable atmospheric conditions created under the influence of the Azores anticyclone.

10 The wavelength dependence of AOD in Nauru (Fig. 4c) is quite similar throughout the year, being very small. The small intra-annual variability is indicated by monthly values of Angstrom parameter varying within the range $0.12-0.75$, i.e. not far from the mean annual values of $0.31-0.51$ (see Fig. 2c). Note the relatively higher AOD values in September, especially at the smaller wavelengths, which are associated with a relatively steep spectral decrease of AOD ( $\alpha$ value of 0.75 ). This indicates the presence of fine particles in this month. However, the high AOD values presented on some days in September 2002 are not in agreement with the MODIS data for the same days. Also, back-trajectory analysis does not indicate air-masses originating from continental areas. Therefore, these AOD and $\alpha$ values maybe include uncertainties due to instrumental inaccuracies under low turbid conditions. Note also the almost flat spectral profile of AOD in the wavelengths above $500 \mathrm{~nm}$. This, as also indicated for the mean annual profile (cf. Fig. $3 \mathrm{c}$ ) is due to the presence of coarse maritime particles prevailing in this remote oceanic location.

As far as it concerns Solar Village (Fig. 4d), the weak AOD wavelength dependence 25 is indicative of significant contribution from coarse-mode particles. This is also reflected in the small $\alpha$ values (range $0.19-0.83$ ) over all seasons, but particularly in the period from March to June ( $\alpha$ values $0.19-0.34$ ). The flat spectral profile of AOD in spring and early summer, together with the occurrence of largest values in those months for the specific site $(0.4-0.55)$ suggest that the aerosol population is dominated by

\section{Climatology of different aerosol types}

D. G. Kaskaoutis et al.

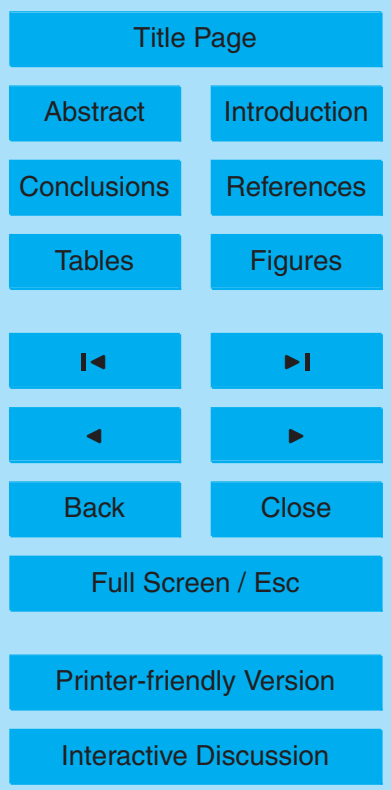


dust produced in surrounding areas under favorable weather conditions. On the contrary, during fall (October-November) the decrease in AOD with increasing wavelength is more remarkable ( $\alpha$ values of about 0.8 ) indicating a contribution from fine-mode particles, produced by anthropogenic or natural sources. The aerosol seasonal vari5 ation over this site is mainly driven by natural sources closely related to the meteorological patterns and the climatology of the area. The long-term climatology over the Arabian Peninsula has enabled the following seasonal divisions: southwesterly monsoon (June-September), fall transition (October-November), northeasterly monsoon (December-March), and spring transition (April-May). During the southwesterly 10 monsoon, a northwesterly flow occurs at all levels over the Arabian Peninsula bringing extremely dry air and dust from the Iraqi deserts. During the fall transition season, winds remain northwesterly but speeds decrease, the frequency of occurrences of dust storms decreases significantly, and air temperatures drop. The northeasterly monsoon is characterized by a very complex airflow pattern, which can be a combination of land15 sea breezes, outflow from the Persian Gulf, and northeasterly flow off the Iranian coast. Dust is usually advected from Saudi Arabia, Iraq, or South Iran (Liu et al., 2000). In the April-May period, winds are predominantly from northern to northwesterly directions; and the frequency of dust storms increases. Similar seasonal differences in the spectral profile of AOD values have also been reported over Korea by Ogunjobi et al. (2004). More specifically, they reported that the wavelength dependence of AOD in April, when the region is strongly influenced by Asian dust, differs significantly from that in October, when biomass burning is dominant.

\subsection{Relationship between AOD and Ångström exponent}

When attempting a realistic characterization of aerosol properties data of both aerosol optical depth and Angstrom parameter have to be used (Holben et al., 2001) since they both depend strongly on wavelength (Reid et al., 1999; Kaskaoutis and Kambezidis, 2006). To this end, values of AOD at $500 \mathrm{~nm}$ are usually used, because they are indicative of the turbidity conditions and aerosol type (Cachorro et al., 2001) together

\section{Climatology of different aerosol types}

D. G. Kaskaoutis et al.

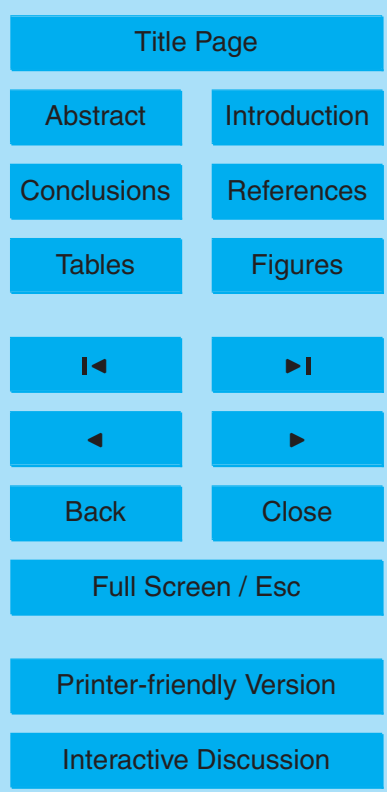


with $\alpha$ value in a wide range of wavelengths $(440-870 \mathrm{~nm})$. Thus, scatter plots of AOD versus $\alpha$ can be obtained in order to determine different aerosol types for a specific location through determination of physically interpretable cluster regions in the diagram. In general, very different patterns in AOD- $\alpha$ scatter plots are reported in the literature 5 (e.g. Holben et al., 2001) making thus difficult any interpretation. Nevertheless, the Angstrom parameter $\alpha$ depends strongly on the pair of wavelengths used for its determination. Therefore, the detailed spectral information given by the determination of $\alpha$ in different spectral pairs can help in determining and discriminating between the different aerosol types (Cachorro et al., 2001). In a first step, in Fig. 5, the relationship 10 between $\mathrm{AOD}_{500}$ and $\alpha_{440-870}$ is given for the four selected sites in a common scatter plot diagram in terms of comparison.

In Alta Floresta, there is a wide range of $\alpha$ values at low $\operatorname{AOD}_{500}(<0.1)$, reflecting thus continental conditions with strong variability in the dominant aerosol properties. The increasing values of $\alpha$ with increasing $\mathrm{AOD}_{500}$ indicate the significant contribu-

tho of fine "fresh-smoke" particles in the atmospheric column, especially under high turbidity. The increasing trend of $\alpha$ with $\mathrm{AOD}_{500}$ is better simulated by a logarithmic formula $\left\{\alpha=0.178 \ln \left(\mathrm{AOD}_{500}\right)+1.711\right\}$ associated with $17.2 \%$ of the variance. A similar relationship between particle concentration (through AOD) and particle size (through Ångström exponent) has been observed for a variety of fine-mode aerosols (Porter and Clarke, 1997; Remer et al., 1998). Reid et al. (1999) suggested several reasons for the co-variance of $\alpha$ with optical depth in Brazil: i) the growth rate of the count median diameter is roughly linearly related to the particle concentration; ii) the growth of the particles by diffusion-limited processes (such as condensation) occurs more rapidly at higher particle concentrations; iii) Reid and Hobbs (1998) showed that, for the same combustion efficiency, large fires produce larger particles; iv) as particles grow in size, they become more efficient light scatterers.

The scatter plot of $\mathrm{AOD}_{500}$ versus $\alpha_{440-870}$ in Ispra, exhibits high dispersion for low optical depths $(<0.1)$, with values of $\alpha_{440-870}$ ranging from $\sim 0.5$ to $\sim 2.5$; this suggests that under relatively clean atmospheric conditions very different aerosol types can be

\section{Climatology of different aerosol types}

D. G. Kaskaoutis et al.

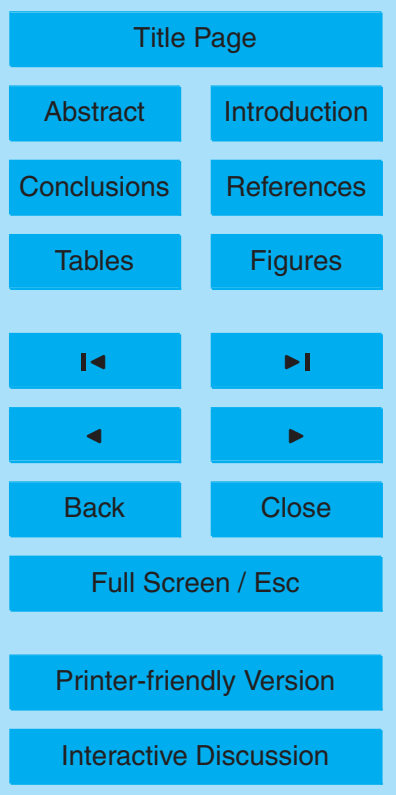


found over Ispra (from pure fine-mode pollutants to coarse-mode particles). There is a slight reduction of $\alpha_{440-870}$ as AOD increases; this reflects the transition of fine-mode particles to accumulation-mode through coagulation, condensation and gas-to-particle conversion. A similar pattern has been observed at several locations and for different 5 aerosol types (e.g. biomass smoke, anthropogenic aerosols, desert dust) (Eck et al., 1999, 2001a, 2001b; Masmudi et al., 2003; Kim et al., 2004; Ogunjobi et al. 2004). The majority of points in the scatterplot diagram for Ispra are confined in the area corresponding to $\alpha_{440-870}>1.5$ for $\mathrm{AOD}_{500} \leq 1$, indicating the presence of fine particles of urban and industrial anthropogenic origin. However, there is also a large population 10 of points corresponding to a great range of $A O D_{500}$ values (from close to zero up to 1.5), which are characterized by intermediate values of $\alpha_{440-870}$ (between 0.5 and 1.5). These cases correspond to mixed aerosol types, making thus difficult the further characterization of urban/industrial aerosols, because of the complex combination of natural and anthropogenic factors (including relative humidity, cloudiness, altitude, 15 fuel types and emission characteristics) that influence aerosol formation and evolution. In conclusion, according to our analysis, the discrimination of aerosol types in Ispra should be limited to cases with large AOD values (>1.5). Besides, this is the reason for which the derivation of aerosol properties (single scattering albedo, asymmetry factor, refractive index) is made through the algorithm of Dubovik and King (2000) only for high AODs using the CIMEL sky-almucantar measurements (Eck et al., 1999; Dubovik et al., 2000; Schuster et al., 2006).

As far as it concerns Nauru, we see that all points are situated towards the left-hand axis, close to zero $\mathrm{AOD}_{500}$ values, with $\alpha_{440-870}$ ranging from slightly negative values $(-0.06)$ up to 1.40 . This results in a very weak anti-correlation between $\alpha_{440-870}$ and $25 \mathrm{AOD}_{500}$ with a correlation coefficient equal to $\mathrm{r}=-0.26$, explaining only $12 \%$ of the variance. Nevertheless, the negative correlation between the two parameters reflects the increasing influence of a fine-aerosol background on AOD in remote oceanic atmospheric conditions. A large number of points $(\sim 75 \%)$ are found in the area with small values of $\alpha_{440-870}(\leq 0.5)$; these are mostly points with the relatively largest values of

\section{Climatology of different aerosol types}

D. G. Kaskaoutis et al.

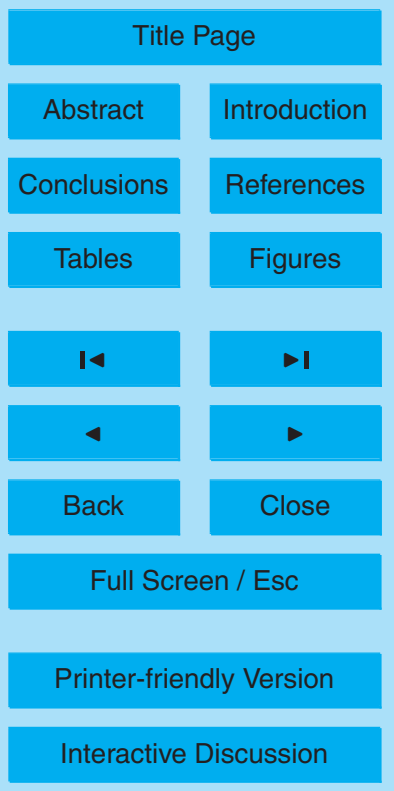


$\mathrm{AOD}_{500}$ in Nauru (up to 0.16 , see Fig. 2c). These points are related to coarse maritime

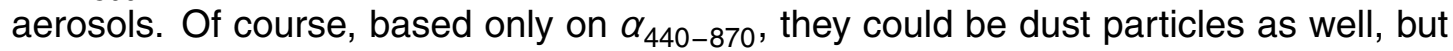
this is excluded since areas of dust are extremely distant and moreover, the occurrence of dust is associated with values larger than 0.1 (see Fig. 2). The rest of points $5(\sim 25 \%)$ are situated in the area with $\alpha_{440-870}>0.5$, corresponding to maritime aerosol conditions, but with influence from fine particles as well.

In Solar Village there is a negative correlation between $\mathrm{AOD}_{500}$ and $\alpha_{440-870}$, despite the large scatter of data points. More specifically, there is a wide range of $\alpha_{440-870}$ values (from about 0.1 to 1.6$)$ for moderate-to-low AODs $(<0.5)$. Nevertheless, 10 for larger values of $A D_{500}(\geq 0.5)$ the Ångström parameter is always smaller than 0.5 , indicating thus the presence of coarse particles, which correspond to dust aerosols. The dominating presence of large particles (radius $>0.6 \mu \mathrm{m}$ ) in desert aerosol is the principal feature differentiating the optical properties of dust from the fine-mode dominated biomass-burning and urban/industrial aerosols (Dubovik et al., 2002). Apart 15 from clear dust conditions, there is a significant number of cases $(\sim 50 \%)$ with $\alpha_{440-870}$ values lying between 0.5 and 1.5. Such Ångström exponent values are indicative of bi-modal aerosol size distributions, with significant contribution from both fine-mode submicron (radius $<1 \mu \mathrm{m}$ ) and coarse-mode supermicron (radius $>1 \mu \mathrm{m}$ ) aerosols (Eck et al., 1999, 2001a). An interesting example of aerosol mixing has been discussed by 20 Eck et al. (1999). They showed a case with values of $\alpha$ and $\mathrm{AOD}_{500}$ of 1.0 and 0.43 respectively, resulting from the mixing of dust and industrial aerosols; the mixing led to a size distribution having accumulation and coarse-mode particles of similar magnitude. In Solar Village, the coarse-mode particles can easily be mixed with pollution aerosols transported from the neighboring industrialized areas of the Persian Gulf or with smoke 25 from oil fires (see Smirnov et al., 2002a). Such a mixture has been reported (Dubovik et al., 2002) to increase the AOD wavelength dependence and strongly modify the spectral single scattering albedo.

Our results show that the mixed-aerosol type is very common in the selected representative world locations (with percentage of occurrences ranging from $40 \%$ to $51 \%$ )

\section{Climatology of different aerosol types}

D. G. Kaskaoutis et al.

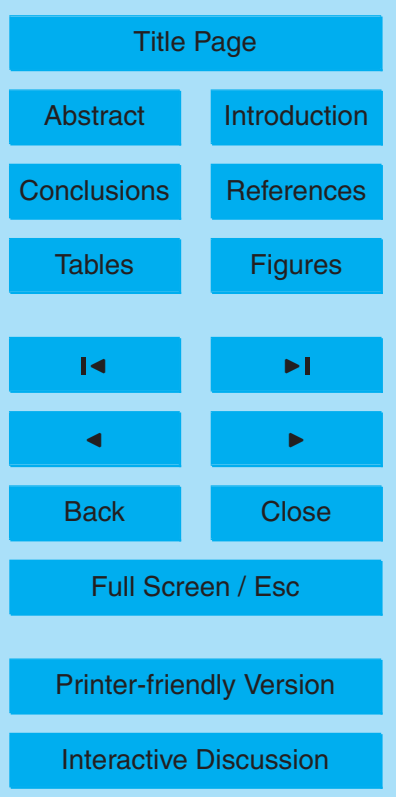


and thus it deserves further discussion. This mixed aerosol type can be the result of independent processes. It can be caused from both primary fine-and coarse-mode particles. In several cases, there are mixtures of both fine-and coarse-mode aerosols resulting in decreasing $\alpha$ as the dust contribution increases. Relative humidity is a de5 termining parameter for the size of aerosol particles (e.g. effective radius), especially for the water-soluble industrial particles, as shown in Seinfeld and Pandis (1997) and from extensive measurements campaigns (e.g. TARFOX). The hygroscopic growth at high relative humidities increases the AOD, due to the enlargement of accumulationmode particles, such as sulfates, which are produced in coal combustions (Ferrare et 10 al., 2000). The growth is largest for hygroscopic and water-soluble particles (Day and Malm, 2001). On the contrary, both aircraft and ships in-situ measurements of finemode (pollution) aerosols in the coasts of Korea and Japan during ACE-Asia showed that the pollution aerosols are moderately-to-strongly hygroscopic (Carrico et al., 2003). The urban conditions in Ispra are likely quite similar to those reported before. In addition to hygroscopic growth, the aging processes of coagulation, condensation and gasto-particle conversion have also been reported to contribute to the growth of smoke aerosols (Reid et al., 1998). Consequently, the presence of both fine- and coarsemode particles over Ispra leads to bi-modal size distributions and hence to intermediate Ångström exponent values.

On the other hand, the coarse-mode particles in Solar Village can easily be mixed with pollution aerosols from the neighboring industrialized areas of the Persian Gulf or with smoke from oil fires (Smirnov et al., 2002a), increasing the AOD wavelength dependence and strongly modifying the spectral single scattering albedo (Dubovik et al., 2002). Finally, the maritime aerosols can be mixed with the continental ones, both 25 natural and anthropogenic, transported over long-range distances. All the above processes contribute to the good mixing of the aerosols in the atmosphere. However, the uncertainties of the aerosol impact on climate remain significant. In addition, the difficulties in radiative- transfer models to represent the real atmospheric conditions are large, thus resulting in high inaccuracies in the prediction of the spectral irradiance at

\section{Climatology of different aerosol types}

D. G. Kaskaoutis et al.

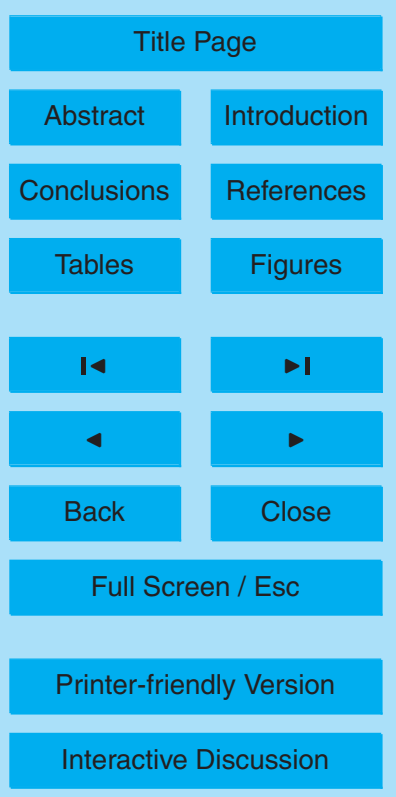

EGU 
the surface of the earth.

In general, it has been reported (e.g. Schuster et al., 2006) that values of Angstrom parameter $<1.0$ indicate size distributions dominated by coarse-mode aerosols (radii $>0.5 \mu \mathrm{m}$ ) that are typically associated with dust (e.g. Solar Village in 5 our study) and sea salt (e.g. Nauru in our study). On the contrary, values of $\alpha>2.0$ (e.g. in Alta Floresta and Ispra in our study) indicate size distributions dominated by fine-mode aerosols (radii $<0.5 \mu \mathrm{m}$ ) that are usually associated with urban pollution and biomass burning. Our analysis indicates that a classification scheme for aerosols in the selected four representative AERONET sites is possible for discriminating between 10 different aerosol types. Therefore, we make a first attempt for classifying the aerosols as it follows. The aerosols are divided into four categories based on their $\mathrm{AOD}_{500}$ and $\alpha_{440-870}$ values. The selected threshold values of $\mathrm{AOD}_{500}$ and $\alpha_{440-870}$ are the same with those of Pace et al. (2006) who discriminated the aerosols over the Mediterranean. According to this scheme: a) values of $\mathrm{AOD}_{500}<0.06$ and values of $\alpha_{440-870}<1.3$ 15 represent clean maritime background conditions (type I, MT), characteristic of remote oceanic areas, b) values of $\mathrm{AOD}_{500}>0.1$ and $\alpha_{440-870}>1.5$ correspond to biomassburning and urban/industrial aerosols (type II, BU), and c) values of $A O D_{500}>0.15$ associated with $\alpha_{440-870}<0.5$ are indicative of desert particles (type III, DD). The cases, which do not belong to any of the above groups, are characterized as mixed-type (type IV, MT) aerosols, which represent the fourth aerosol class.

In the scatterplot diagram of $\mathrm{AOD}_{550}$ versus $\alpha_{440-870}$ (Fig. 5) the four aerosol classes (types) have been divided by solid lines corresponding to the threshold values of $\mathrm{AOD}_{500}$ and $\alpha_{440-870}$. It is characteristic that $100 \%$ of the particles in part I originate from Alta Floresta and Ispra, whereas $97 \%$ of cases in part III originate from Solar Vil-

25 lage; these are the most well defined cases, with the absolute majority of cases being attributed to specific stations. On the other hand, the $57 \%$ of total cases (i.e. a relative majority) in part II, i.e. clean maritime aerosol conditions, are attributed to Nauru. As for type IV (mixed aerosol type), it is identified in all four representative stations.

Correlations between $\mathrm{AOD}_{500}$ and Angstrom wavelength exponent computed at

\section{Climatology of different aerosol types}

D. G. Kaskaoutis et al.

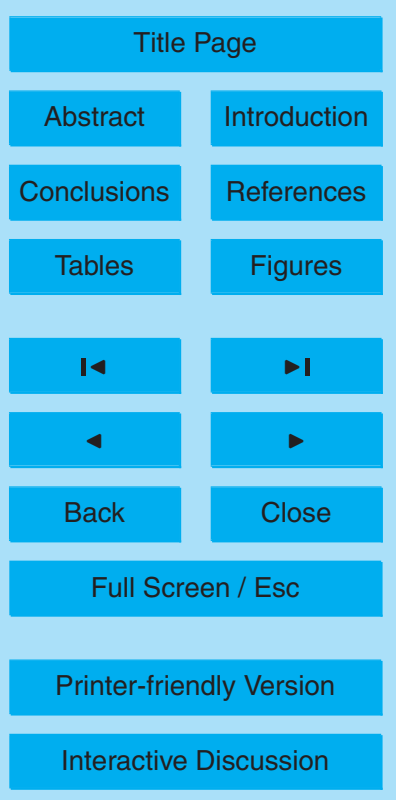


short (380-440 nm) and long (675-870 nm) wavelengths are helpful for parameterizing aerosols in climate models and satellite-remote sensing. Presenting spectral aerosol optical properties, such as Angstrom exponent, as regressions with spectral AOD for different aerosol types helps to outline the dynamics of the aerosol optical properties 5 associated with the growth of the aerosol mass and aerosol processes (aging, particle size and composition transformations) stimulated by the accumulation of aerosols in the atmosphere (Reid et al., 1999). Previous studies (e.g. Reid et al., 1999; O' Neill et al., 2001; Schuster et al., 2006) have shown that Angstrom parameter, $\alpha$, computed from AODs at visible-to-near-infrared wavelengths can provide information on the rel10 ative influence of coarse-versus accumulation-mode aerosols, while $\alpha$ computed in the UV-to-visible wavelengths is much more sensitive to the size of the accumulationmode aerosols with less influence from the coarse-mode ones. Many previous studies (e.g. Reid et al. 1999; Schuster et al., 2006) have shown the usefulness of plotting $\mathrm{AOD}_{500}$ versus $\alpha_{380-440}$ or $\alpha_{675-870}$. The same plots for each representative AERONET 15 station are given in Fig. 6 . Although both the wavelength exponent $\alpha$ and the turbidity coefficient $\beta$ in the Ångström empirical formula ${ }^{1}$ are assumed to be independent from each other and from wavelength, it is well known that both parameters depend on wavelength (Shifrin, 1995). This introduces a curvature effect in the InAOD plotted versus In (Eck et al., 1999, 2001a, 2001b; O' Neill et al., 2001). In each panel of Fig. 6 there are given the computed mean and standard deviation values of $\alpha$ (for both pairs of wavelength, blue for 380-440 and red for 675-870). In all sites, there is a large scatter of both $\alpha_{380-440}$ and $\alpha_{675-870}$, for moderate-to-low $\mathrm{AOD}_{500}$ values $(<0.5)$ against converging values of Angstrom parameter towards larger AODs. Based on $\alpha$ values, the sites can be divided in two groups: a) Alta Floresta and Ispra, and b) Nauru and 25 Solar Village. In the first group, in general, the $\alpha_{675-870}$ values are larger than those of $\alpha_{380-440}$, while the opposite is found for the second group. However, note that the computed mean $\alpha_{675-870}$ value for Alta Floresta (1.15) is smaller than that of $\alpha_{380-440}$ (1.31). This is due to the very small $\alpha_{675-870}$ values for AODs $<0.1$, which are not typical

$$
{ }^{1} \mathrm{t}_{\alpha \lambda}=\beta \lambda^{-\alpha}
$$

\section{Climatology of different aerosol types}

D. G. Kaskaoutis et al.

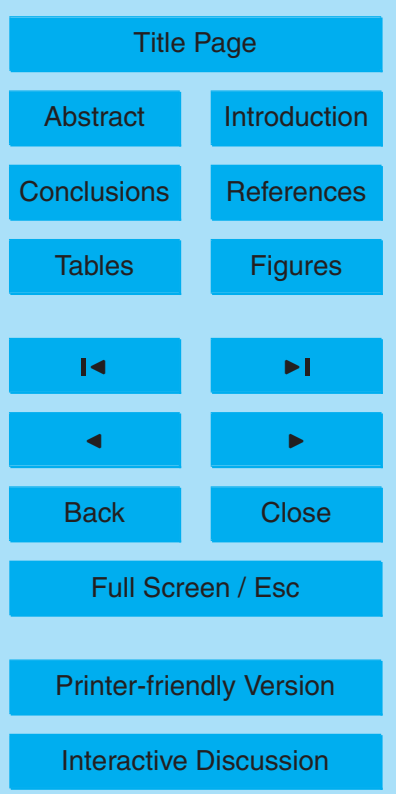

EGU 
of biomass-burning conditions, and it is also indicated by the large standard deviation (0.8). In contrast, for $\mathrm{AOD}_{500}>0.5$ the $\alpha_{675-870}$ values are clearly larger than those of $\alpha_{380-440}$. The larger values of $\alpha_{675-870}$ (at longer wavelengths) than $\alpha_{380-440}$ (at shorter wavelengths) are characteristic of fine-mode particles, thus leading to a negative cur5 vature (convex type) of InAOD plotted versus In $\lambda$ (Eck et al., 1999, 2001b). In Ispra, the differences between the $\alpha_{675-870}$ and $\alpha_{380-440}$ values are smaller than those in Alta Floresta, implying thus a weaker wavelength dependence of Ångström parameter, and hence a smaller curvature effect of spectral AOD values. For both sites, the differences in $\alpha$ values are bigger for larger $\mathrm{AOD}_{500}$ values. This implies that the spectral 10 dependence of $\alpha$ and, therefore, the curvature effect, is stronger for higher concentrations of fine-mode aerosols, as also stated by Eck et al. $(1999,2005)$ and Schuster et al. (2006). On the other hand, in Nauru and Solar Village the $\alpha_{380-440}$ values are larger than those of $\alpha_{675-870,}$ implying thus a positive curvature effect (concave type) of InAOD plotted versus $\ln \lambda$. This indicates the presence of coarse-mode aerosol parti-

15 cles (e.g. Eck et al., 1999; Schuster et al., 2006). The ratio of mean $\alpha_{380-440} / \alpha_{675-870}$ values is larger in Nauru (even becoming negative) than in Solar Village, indicating thus a quite stronger effect in the former site than in the later. In Nauru, the computed mean $\alpha_{380-440}$ value (1.38) is quite large compared to that in Solar Village (0.86); this is due to the existence of high AOD values at $380 \mathrm{~nm}$ (see Fig. 4c) in Nauru. On the other hand, 20 note that the $\alpha_{675-870}$ value in Nauru (-0.02) is negative, against a corresponding value equal to 0.5 in Solar Village. In general, despite the large scatter of data points in both locations (Figs. $6 \mathrm{c}$ and d), the $\alpha_{380-440}$ values decrease with increasing $\mathrm{AOD}_{500}$. As far as it concerns $\alpha_{675-870}$, itis practically independent from turbidity in Nauru, whereas in Solar Village it decreases with $\mathrm{AOD}_{500}$, indicating thus that coarse aerosols dominate, 25 and also that the ratio of coarse/fine aerosols increases, under conditions of high turbidity. The differences between $\alpha_{675-870}$ and $\alpha_{380-440}$ values are generally small, and they become practically zero for $\mathrm{AOD}_{500}>0.7$. This implies a weak spectral dependence of the Angstrom parameter $\alpha$, and therefore, a better efficiency of the empirical Ångström formula for obtaining spectral AOD values.

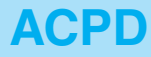

$7,6357-6411,2007$

\section{Climatology of different aerosol types}

D. G. Kaskaoutis et al.

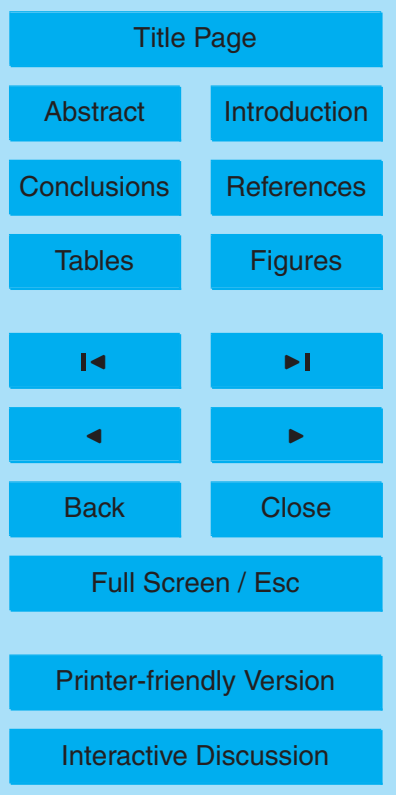




\subsection{Seasonal discrimination of aerosol types}

The methodology described in the previous sub-section was applied to discriminate and classify aerosol populations over the selected four representative AERONET sites into the defined aerosol types. The analysis was performed on a monthly basis, and 5 the results are given in Table 2 on a year and seasonal basis.

In Alta Floresta, on a year basis, the mixed-type (MT) of aerosols occurs most frequently, i.e. in $51.5 \%$ of total cases. In particular, during winter and spring the frequency of occurrence of MT becomes maximum (75-77\%). Only in summer and autumn (i.e. the burning season) the frequency of MT is not dominant, the majority of aerosols being of biomass-urban (BU) type, with frequencies up to 59 and $64 \%$, respectively. However, even in these seasons, a considerable fraction ( $36 \%)$ of aerosols is MT. Our analysis on a monthly basis, revealed that the majority of these cases occurs in the pre-burning (June-July) or post-burning (October-November) seasons. It is worth noting that during August and September (the burning season) the frequency of BU 15 aerosol type is as high as $92.4 \%$. During winter and spring, the frequency of $\mathrm{BU}$ is very small $(<11 \%)$ related to aged-smoke particles given that the associated $A O D_{500}$ values are above 0.5. Desert dust (DD) is practically absent in Alta Floresta, whereas the frequency of clean maritime (CM) aerosol conditions is small (6\% on a year basis) being largest in winter $(\sim 7 \%)$ and spring $(\sim 15 \%)$.

20 In Ispra, the majority of cases (47.2\% on a year basis) corresponds to the BU aerosol type, with mixed aerosols (MT) being the secondarily most frequent (38.5\%). Desert dust aerosols are absent, whereas clean maritime conditions appear in $13.7 \%$ of total cases. The frequency of BU aerosols becomes maximum ( 65\%) in summer, i.e. when there are stable atmospheric conditions and absence of wet removal processes, but 25 also in autumn ( 53\%). Aerosols of clean maritime type are found throughout the year (frequencies between 6 and 26\%), with the highest frequency in winter, i.e. when precipitation removes efficiently aerosols. The mixed aerosol type is common throughout the year (frequencies within the range $27-59 \%$ ), whereas there is a systematic ab-

\section{Climatology of different aerosol types}

D. G. Kaskaoutis et al.

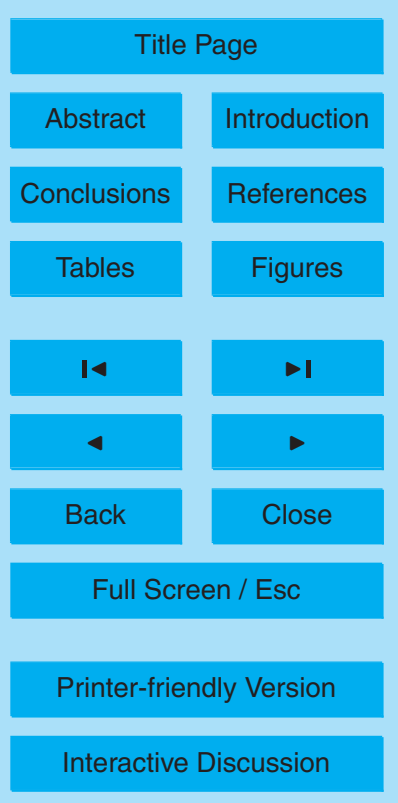


sence of desert dust (frequencies $<2 \%$ ) due to the large distance of Ispra from the exporting source desert areas of Sahara in north Africa, so that DD particles are efficiently mixed with aerosols emitted from local sources during their transport up to Ispra.

5 In the remote ocean area of Nauru, the majority of cases (56.7\% on a year basis) are of $\mathrm{CM}$ aerosol type, as expected. Nevertheless, there is also a significant contribution (40.3\%) by MT aerosols. The predominance of CM to other aerosol types exists over all seasons, but it is less remarkable in the spring-summer period, when the continental aerosol contribution is larger. Especially during spring, $4.6 \%$ of the aerosols are of 10 DD type corresponding to aerosols transported from the arid areas of East Asia and Australia. Especially, during this season, strong Asian dust outflows to the Pacific Ocean have been reported in literature (e.g. Smirnov et al., 2002b; Kim et al., 2004; Eck et al., 2005). Note that the BU type is totally absent in this remote oceanic site.

In Solar Village, the majority of aerosol types are DD (47\%), and MT (50\%) on a 15 year basis. However, the frequencies of MT are even higher in winter, late summer and autumn, when moderate turbidity conditions prevail (see Fig. 2). Although the presence of $\mathrm{CM}$ aerosols is rare (3.7\% on a year basis) this becomes significant in winter, when the fraction of cases characterized as $\mathrm{CM}$ is about half of that for DD aerosols. The frequency of occurrence of DD aerosols becomes as high as about $80 \%$ in spring, whereas our analysis revealed frequencies of DD as large as $97.7 \%$ in May, when the majority of dust outflows occurs. The BU aerosol type is absent in this site, which is too far to be practically unaffected from any industrial activities or possible oil fires in the Persian Gulf (Smirnov et al., 2002a).

A small modification of the threshold values in the scheme for aerosol classification can potentially lead to significant changes in the above percentages of occurrence of the four different aerosol types (BU, CM, DD and MT). To assess this, we changed a bit the threshold values for the discrimination of the different aerosol types. The more detectable changes were found for the BU and DD aerosol types. Thus, it was found that a decrease of the threshold $\alpha_{440-870}$ value from 1.5 to 1.4 increases the yearly

\section{Climatology of different aerosol types}

D. G. Kaskaoutis et al.

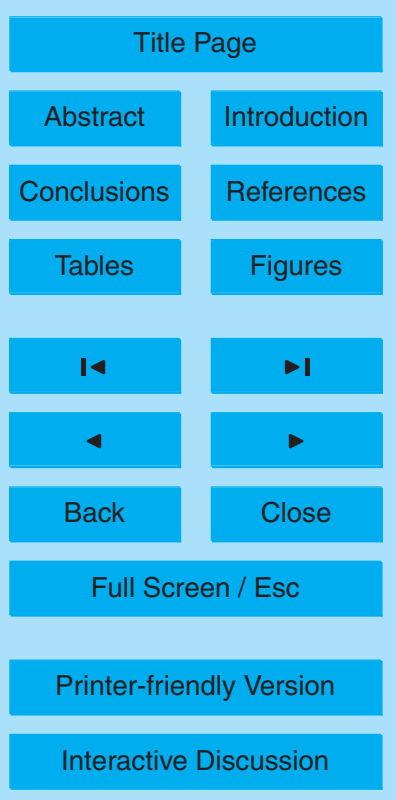

EGU 
frequency of occurrence of BU from $41.8 \%$ to $46.2 \%$ in Alta Floresta and from $47.2 \%$ to $54.6 \%$ in Ispra. Similarly, an increase of $\alpha_{440-870}$ from 0.5 to 0.6 increases the frequency of DD aerosol type in Solar Village from $46.6 \%$ to $52.4 \%$.

The seasonal discrimination and classification of aerosols was further investigated 5 using aerosol optical depth and Ångström parameter values. At first, a classification of aerosol types was performed based on $\mathrm{AOD}_{500}$ values. For each site and season the frequency of occurrence of each aerosol type is given in Figs. 7, 8, 9 and 10. Similar information was given in Table 2, but here further information is given for each interval of $\mathrm{AOD}_{500}$. Second, the classification is also attempted based on the $\alpha$ values, and the 10 results are given for each season including the four sites (Figs. 11-14). Obviously, the frequency distribution of the four aerosol types is very different from site to site, whereas it varies strongly with season. A similar classification of different aerosol types was applied by Pace et al. (2006) at Lambedusa (central Mediterranean) based on AOD, $\alpha$ values and air-mass trajectories. Also, Barnaba and Gobbi (2004) discriminated three 15 aerosol types (urban-continental, maritime and desert dust) over the Mediterranean based on the relationship between AOD and fine-mode fraction.

In Alta Floresta (Fig. 7) the BU type (in red) is dominant in summer and autumn, while in winter and spring the MT dominates, as also indicated in Table 2. Nevertheless, note that in summer, under clean background aerosol conditions $\left(A O D_{500}<0.2\right)$ the MT aerosol type dominates, In addition, note that in general, under clean background aerosol conditions the MT aerosols occur most frequently throughout the year. During winter and spring, large $A O D_{500}$ values $(>0.8)$ are absent. In summer, for $A D_{500}>0.4$, the aerosols are always of BU type, opposite to autumn, when the occurrence of MT is significant for all $A O D_{500}$ intervals (frequency about half of that of $\mathrm{BU}$ ). The $\mathrm{CM}$ aerosol conditions occur only for small $A \mathrm{DD}_{500}$ values $(<0.2)$ during winter, spring and summer, whereas $\mathrm{DD}$ aerosols occur extremely rarely during winter and spring, contributing to large $\mathrm{AOD}_{500}$ values for the seasonal standards.

The aerosol classification is more complex for Ispra (Fig. 8). Large $A D_{500}$ values $(>1.0)$ occur in all seasons. In general, the BU aerosol type is prevalent in summer

\section{Climatology of different aerosol types}

D. G. Kaskaoutis et al.

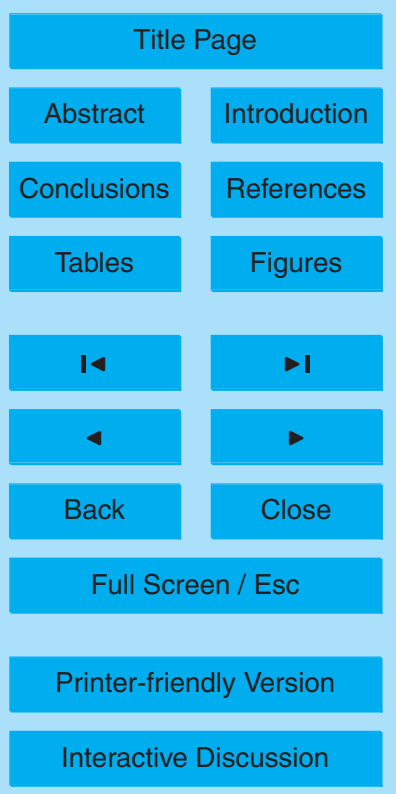

EGU 
and autumn, whereas the MT aerosol type dominates in winter and spring. Moreover, MT aerosols are the most frequent for $\mathrm{AOD}_{500}>0.6$, in all seasons. Apart from this, there is a significant contribution of $\mathrm{CM}$ aerosols for clean atmospheric conditions $\left(A O D_{500}<0.2\right)$. Note the very low frequency of DD aerosols. For turbid atmospheric 5 conditions $\left(\mathrm{AOD}_{500}>1.0\right)$ the most prevalent (but at low frequencies) aerosol types are the MT and, to a lesser extent, the BU and DD ones.

The discrimination of aerosol types in Nauru (Fig. 9) is clear for all seasons. Thus, for clean atmospheric conditions $\left(\mathrm{AOD}_{500} \leq 0.06\right) \mathrm{CM}$ aerosols dominate, while for more turbid atmosphere $\left(\mathrm{AOD}_{500}>0.06\right) \mathrm{MT}$ aerosols are the most frequent. Therefore, 10 it appears that for clean background conditions, the aerosol population is consisted from maritime aerosols, which is reasonable given the location of the station. On the contrary, when more pollutants are found in the local atmosphere, leading to relatively larger $\mathrm{AOD}_{500}$ values, these pollutants are superimposed to background maritime aerosols resulting in a mixture of aerosols (MT type). Note that for large aerosol loads $15 \quad\left(\mathrm{AOD}_{500}>0.14\right)$ there is a frequent occurrence of DD aerosols in all seasons. These aerosols are transported from the Australian or East Asian deserts, and their occurrence is dominant in all seasons except for autumn.

Similarly to Nauru, in Solar Village (Fig. 10) the discrimination of aerosols is simple. The only aerosol types occurring are those of DD and MT. It is only during clean winter atmospheric conditions that $\mathrm{CM}$ aerosols are found. For turbid conditions $\left(\mathrm{AOD}_{500}>0.4\right.$ in winter and spring and $A O D_{500}>0.6$ in summer) the $\mathrm{DD}$ aerosols dominate, especially in spring when the majority of dust outflows takes place. On the other hand, for clean background atmospheric conditions, the aerosols are well mixed (MT type) in all seasons. Especially, during summer and autumn, the MT aerosols dominate even in more polluted atmospheres $\left(\mathrm{AOD}_{500}\right.$ of up to $\left.0.4-0.6\right)$.

The classification of aerosol types based on Ångström $\alpha_{440-870}$ values instead of $\mathrm{AOD}_{500}$, is given in Figs. 11 to 14. In Alta Floresta (Fig. 11) all aerosol types occur during winter. The overall dominant MT type for this season (mean frequency of $77.8 \%$ on a seasonal basis, see Table 2) occurs in a broad range of Ångström parameter

\section{Climatology of different aerosol types}

D. G. Kaskaoutis et al.

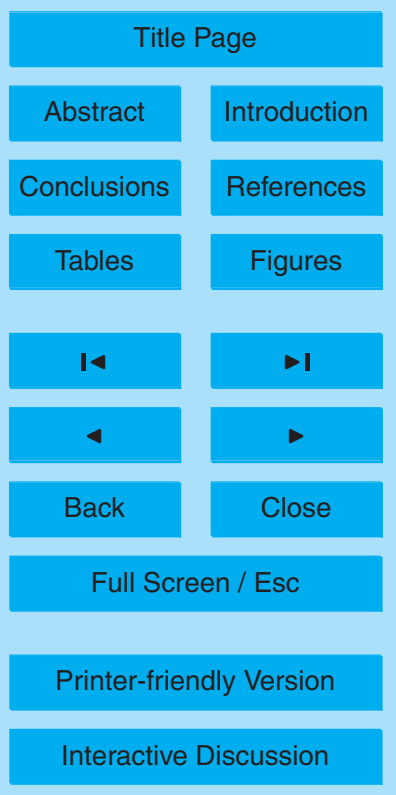


values, extending from $<0.3$ (corresponding to coarse particles) to 2.4 (fine particles). It is only in cases of large $\alpha_{440-870}$ values that BU aerosols $\left(\alpha_{440-870}>1.5\right)$ appear as frequently as MT particles, whereas for small $\alpha_{440-870}$ values smaller than 0.6 the DD aerosols are also present. The CM aerosols appear with low frequencies in cases 5 with $\alpha_{440-870}$ values between 0.6 and 1.2. During spring there is a rather complicated pattern, with all aerosol types occurring in Alta Floresta, which is very similar to that of winter. On the contrary, the situation is more clear during summer and autumn, when only BU and MT aerosols occur, with the BU particles being the most frequent, as also stated in Fig. 7.

10 The seasonal patterns of aerosol discrimination in Ispra (Fig. 12) are very similar to those in Alta Floresta, with the difference that the BU aerosols dominate over MT ones at large $\alpha_{440-870}$ values, during winter and spring (this is also valid in both Alta Floresta and Ispra for summer and autumn). This difference is due to the nature of the surrounding region in Ispra, which is a heavily industrialized area, probably among the most industrialized ones in Europe.

The aerosol classification is similar between Nauru (Fig. 13) and Solar Village (Fig. 14) being at the same time very different than that in Alta Floresta and Ispra. More specifically, over all seasons, there is no presence of BU aerosols at all; this is expected since both stations are located at large distances from any source of anthropogenic or biomass burning activity. Nevertheless, there are also differences between them. First, in general, smaller aerosols occur in Solar Village than in Nauru $\left(\alpha_{440-870}\right.$ values up to 1.5 and 1.2, respectively); this is expected given that Nauru is a more remote station than Solar Village. Besides, during winter and spring, the DD aerosols strongly dominate in small $\alpha_{440-870}$ values $(<0.6)$ in Solar Village, while in Nauru AERONET site there are either mixed or $\mathrm{CM}$ aerosols that dominate. Furthermore, during summer and autumn, Nauru is strongly characterized primarily by the presence of $\mathrm{CM}$ aerosols and secondarily by MT ones; on the contrary, in Solar Village, during the same seasons there are whether desert aerosols which are prevalent, especially in summer and for $\alpha_{440-870}$ values $<0.3$ (frequency of $\sim 96 \%$ ) or the mixed aerosol type dominating for

\section{Climatology of different aerosol types}

D. G. Kaskaoutis et al.

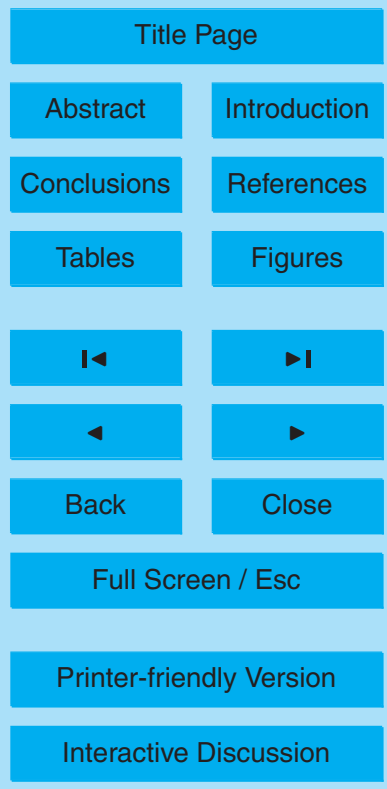




\section{Conclusions}

In this paper, we analyzed spectral measurements of aerosol optical depth (AOD) and Ångström parameter $(\alpha)$ obtained from ground based sunphotometers within the framerepresentative of very different aerosol regimes worldwide. An appropriate methodology was created for discriminating between four different aerosol types: biomass burning-urban (BU), clean maritime (CM), desert dust (DD) and mixed type (MT). The methodology was built taking advantage of the use of aerosol optical properties at different available wavelengths, and the different spectral variability of AOD and Ångström parameter. Subsequently, the methodology was applied to the analyzed 3-year (20022004) data in order to characterize the aerosol properties in each station, and classify the different aerosol types. The analysis was performed using daily aerosol data, whereas the results are presented on a mean monthly, seasonal and annual basis for each station. The main conclusions are summarized as follows:

- There is a significant intra-annual variability of spectral AOD values, especially in sites dominated by biomass smoke (Alta Floresta) and desert dust (Solar Village) with maximum values in seasons of intense fires (August-September) or dust outbreaks (May), respectively. In the urban/industrial site of Ispra and the remote oceanic site of Nauru, the AOD values mainly depend on anthropogenic activities and long-range transport, respectively. Though there are significant differences between the four sites in terms of AOD magnitude, in all sites the smallest AOD values (transparent atmospheric conditions) occur in winter.

- The wavelength dependence of monthly mean AOD varies largely between the four sites, and it is strongly influenced by the existence and relative contribution of coarse-and fine-mode particles. Thus, on an annual basis, a strong decrease of 6386

\section{Climatology of different aerosol types}

D. G. Kaskaoutis et al.

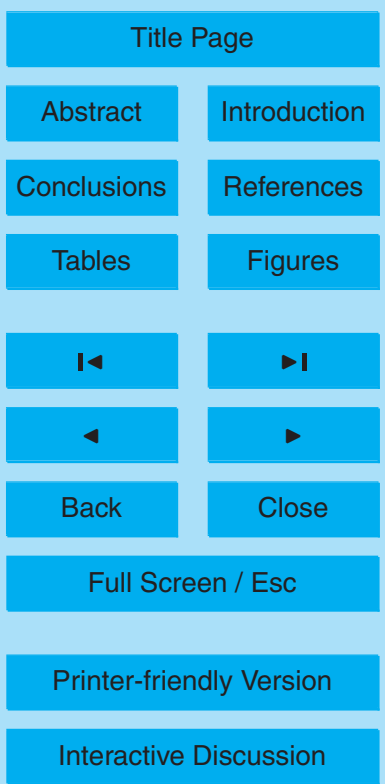

EGU 
AOD values with increasing wavelength was revealed for the sites of Alta Floresta and Ispra, which are dominated by naturally or anthropogenically produced fine particles, against a weaker spectral decrease for Nauru and Solar Village, characterized by the presence of coarse maritime or desert particles. Apart from the differences between the sites in terms of spectral variability of mean annual AOD values, significant differences were also discovered between different months and seasons for a given site, which provide useful information on natural or anthropogenic processes taking place.

- The correlation between the AOD values at $500 \mathrm{~nm}$ and those of $\alpha$ computed at 440 and $870 \mathrm{~nm}$, was found to constitute an appropriate criterion for characterizing and separating the different aerosol types that occur in each location. Nevertheless, a significant number of cases $(38 \%-51 \%)$ could not be characterized as a pure-aerosol type, i.e. clean maritime (CM), biomass burning-urban (BB) or desert dust (DD) due to the efficient atmospheric aerosol mixing processes. These processes (e.g. coagulation, condensation, gas-to-particle conversion, aged processes, humidification, photochemical reactions, scavenging by precipitation) make difficult to attribute aerosols to one of the previous specific aerosol types, leading thus to their characterization as mixed aerosols.

- The aerosol types were classified based on $\mathrm{AOD}_{500}$ and $\alpha_{440-870}$ values, as follows: $\mathrm{BU}\left(\mathrm{AOD}_{500}>0.1\right.$ and $\left.\alpha_{440-870}>1.5\right), \mathrm{CM}\left(\mathrm{AOD}_{500}<0.06\right.$ and $\left.\alpha_{440-870}<1.3\right)$ and DD $\left(\mathrm{AOD}_{500}>0.15\right.$ and $\left.\alpha_{440-870}<0.5\right)$. The cases not belonging to any of these types were characterized as of MT aerosol type. On an annual basis, in Alta Floresta and Ispra AERONET sites, BU is the dominant aerosol type, occurring in $41.8 \%$ and $47.2 \%$ of total cases, while in Nauru the CM $(56.7 \%)$ and in Solar Village the DD aerosol type (46.6\%) were the most frequent aerosol types.

- The annual frequencies of occurrence of different aerosol types were found to vary strongly with season and month. Thus, for example, the BU aerosols in Alta Floresta were found to occur at the extremely high frequency of $92.4 \%$ during 6387

\section{Climatology of different aerosol types}

D. G. Kaskaoutis et al.

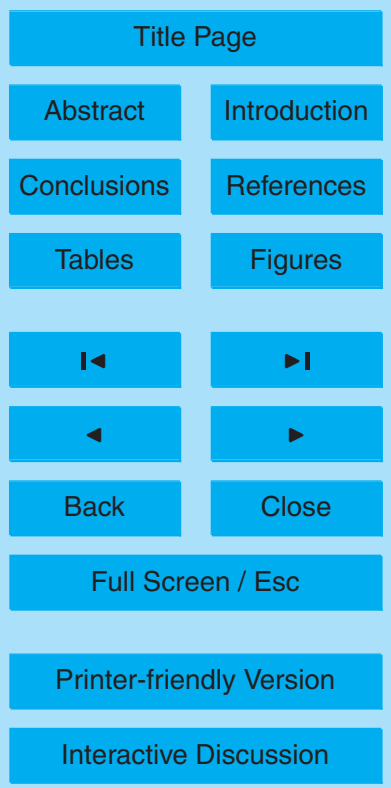

EGU 
the biomass-burning season (August-September) whereas the frequency of DD aerosols in Solar Village is as high as $97.7 \%$ in May.

- The analysis was extended by performing the aerosol classification into the same four aerosol types, but based on the spectrally resolved (in classes) values of AOD and Angstrom parameter. The results reveal clear patterns regarding the frequency of a specific aerosol type in each spectral interval of the AOD or $\alpha$ parameter. These patterns, which depend strongly on the world location and season, provide further information on the aerosol characterization.

The results of our study confirm the large variability of aerosol optical properties with

10

space and time. They show, however, that using detailed spectral values of aerosol optical depth and Ångström parameter is possible to obtain a lot of information that can be the basis for characterizing the aerosol properties, which is highly desired by radiative transfer and climate models. Given that spectral information on aerosol properties is being increasingly available all over the globe (through both ground- and space-based isticated instruments, e.g. AERONET or MODIS, respectively) it is very hopefu that our knowledge on globally distributed aerosols will become much better soon.

Acknowledgements. We thank B. Holben for his effort in establishing and maintaining the Aeronet Alta Floresta site, G. Zibordi for his effort in establishing and maintaining the Aeronet Ispra site, R. Wagener for his effort in establishing and maintaining the Aeronet Nauru site and

\section{References}

Abel, S. J., Highwood, E. J., Haywood, J. M., and Stringer, M. A.: The direct radiative effect of biomass burning aerosols over southern Africa, Atmos. Chem. Phys., 5, 1999-2018, 2005, http://www.atmos-chem-phys.net/5/1999/2005/.

25 Adeyewa, Z. D. and Balogun, E. E.: Wavelength dependence of aerosol optical depth and the fit of the Angstrom law, Theor. Appl. Climat., 74, 105-122, 2003.

\section{Climatology of different aerosol types}

D. G. Kaskaoutis et al.

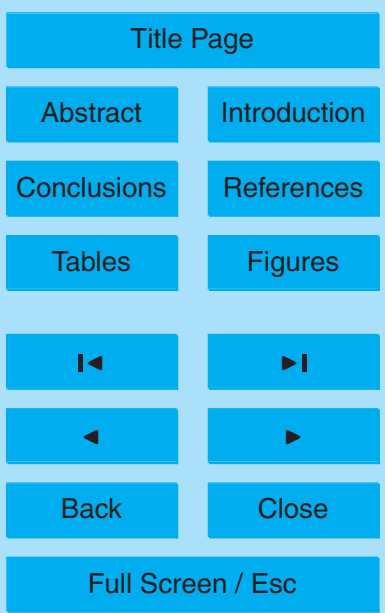

Printer-friendly Version

Interactive Discussion 
Andreae, M. O.: Raising dust in the greenhouse, Nature, 380, 389-390, 1996.

Ångström, A. K.: On the atmospheric transmission of sun radiation and on the dust in the air, Geogr. ANN., 12, 130-159, 1929.

Antoine, D. and Nobileau, D.: Recent increase of Saharan dust transport over the Meditterenean Sea, as revealed from ocean color satellite (SeaWiFS) observations, J. Geophys. Res., 111, D12214, doi:10.1029/2005JD006795, 2006.

Artaxo, P., Gerab, F., Yamasoe, M. A., and Martins, J. V.: Fine mode aerosol composition at three long-term atmospheric monitoring sites in the Amazon Basin, J. Geophys. Res., 99, 22 857-22 868, 1994.

10 Balis, D. S., Amiridis, V., Nickovic, S., Papayannis, A., and Zerefos, C. S.: Optical properties of Saharan dust layers as detected by a Raman lidar at Thessaloniki, Greece, Geophys. Res. Lett., 31, LI3104, doi:101029/2004GL019881, 2004.

Barnaba, F. and Gobbi, G. P.: Aerosol seasonal variability over the Mediterranean region and ralative impact of maritime, continental and Saharan dust particles over the basin from MODIS data in the year 2001, Atmos. Chem. Phys., 4, 2367-2391, 2004, http://www.atmos-chem-phys.net/4/2367/2004/.

Cachorro, V. E., Vergaz, R., and de Frutos, A. M.: A quantitative comparison of $\alpha$ Ångström turbidity parameter retrieved in different spectral ranges based on spectroradiometer solar radiation measurements, Atmos. Environ., 35, 511-7-5124, 2001.

Carrico, C. M., Kus, P., Rood, M. J., Quinn, P. K., and Bates, T. S.: Mixtures of pollution, dust, sea salt, and volcanic aerosol during ACE-Asia: Radiative properties as a function of relative humidity, J. Geophys. Res., 108(D23), 8650, doi:101029/2003JD003405, 2003.

Claquin, T., Schulz, M., Balkanski, Y., and Boucher, O.: Uncertainties in assessing radiative forcing by mineral dust, TellusB, 50, 491-505, 1998.

Collaud Coen, M., Weingartner, E., Schaub, D., Hueglin, C., Corrigan, C., Henning, S., Schwikowski, M., and Baltensperger, U.: Saharan dust events at the Jungfraujoch: Detection by wavelength dependence of the single scattering albedo and first climatology analysis, Atmos. Chem. Phys., 4, 2465-2480, 2004, http://www.atmos-chem-phys.net/4/2465/2004/.

30 D' Almeida, G. A.: On the variability of desert aerosol radiative characteristics, J.Geophys. Res., 92, 3017-3026, 1987.

Day, D. E. and Malm, W. C.: Aerosol light scattering measurements as a function of relative humidity: a comparison between measurements made at three different sites, Atmos. Environ.,

\section{Climatology of different aerosol types}

D. G. Kaskaoutis et al.

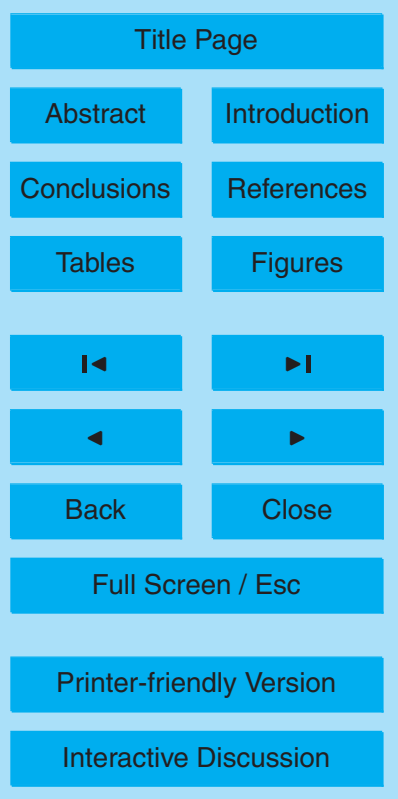


35, 5169-5176, 2001.

Dubovik, O. and King, M. D.: A flexible inversion algorithm for retrieval of aerosol optical properties from sun and sky radiance measurements, J.Geophys. Res., 105, 20 673-20 696, 2000.

Dubovik, O., Smirnov, A., Holben, B. N, King, M. D., Kaufman, Y. J., Eck, T. F., and Slutsker, I.: Accuracy assessments of aerosol properties retrieved from Aerosol Robotic Network (AERONET) sun and sky radiance measurements, J. Geophys. Res., 105, 9791-9806, 2000.

Dubovik, O., Holben, B. N, Eck, T. F., Smirnov, A., Kaufman, Y. J., King, M. D., Tanrè, D., and Slutsker, I.: Variability of absorption and optical properties of key aerosol types observed in 10 worldwide locations, J. Atmos. Sci., 59, 590-608, 2002.

Duncan, B. N., Martin, R. V., Staudt, A. C., Yevish, R., and Logan, J. A.: Interannual and seasonal variability of biomass burning emissions constrained by satellite observations, $\mathrm{J}$. Geophys. Res., 108(D2), 4100, doi:10.1029/2002JD002378, 2003.

Eck, T. F., Holben, B. N, Slutsker, I., and Setzer, A.: Measurements of irradiance attenuation 15 and estimation of aerosol single scattering albedo for biomass burning aerosols in Amazonia, J.Geophys. Res., 103, 31 865-31878, 1998.

Eck, T. F., Holben, B. N., Reid, J. S., Dubovic, O., Smirnov, A., O' Neil, N. T., Slutsker, I., and Kinne, S.: Wavelength dependence of the optical depth of biomass burning, urban, and desert dust aerosols, J. Geophys. Res., 104(D24), 31 333-31 349, 1999.

20 Eck, T. F., Holben, B. N., Dubovic, O., Smirnov, A., Slutsker, I., Lobert, J. M., and Ramanathan, V.: Column-integrated aerosol optical properties over the Maldives during the northeast monsoon for 1998-2000, J. Geophys. Res., 106, 28555-28566, 2001a.

Eck, T. F., Holben, B. N., Ward, D. E., Dubovic, O., Reid, J. S., Smirnov, A., Mukelabai, M. M., Hsu, N. C., O' Neil, N. T., and Slutsker, I.: Characterization of the optical properties of biomass burning aerosols in Zambia during the 1997 ZIBBEE field campaign, J. Geophys. Res., 106(D4), 3425-3448, 2001b.

Eck, T. F., Holben, B. N., Ward, D. E., et al.: Variability of biomass burning aerosol optical characteristics in southern Africa during SAFARI 2000 dry season campaign and a comparison of single scattering albedo estimates from radiometric measurements, J. Geophys. Res., 108(D13), 8477, doi:10.1029/2002JD002321, 2003.

Eck, T. F., Holben, B. N., Dubovic, O., Smirnov, A., Goloub, P., Chen, H. B., Chatenet, B., Gomes, L., Zhang, X. Y., Tsay, S.C., Ji, Q., Giles, D., and Slutsker, I.: Columnar aerosol optical properties at AERONET sites in central eastern Asia and aerosol transport to the

\section{Climatology of different aerosol types}

D. G. Kaskaoutis et al.

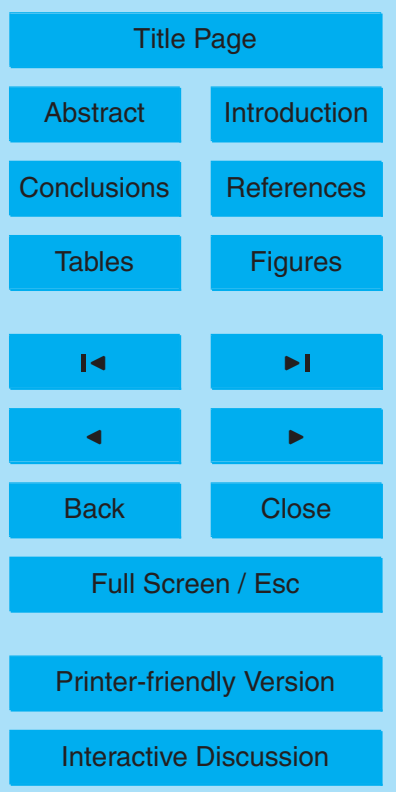

EGU 
tropical mid-Pacific, J. Geophys. Res., 110, D06202, doi:10.1029/2004JD005274, 2005.

Ferrare, R., Ismail, S., Browell, E., et al.: Comparison of aerosol optical properties and water vapor among ground and airborne lidars and sun photometers during TARFOX, J. Geophys. Res., 105, 9917-9933, 2000.

5 Fouquart, Y., Bonnel, B., Brgniez, J. C., Buriez, L., Smith, L., and Morcrette, J. J.: Observation of Saharan aerosols: results of ECLATS field experiment: II. Broadband radiative characteristics of the aerosols and vertical radiative flux divergence, J. Clim. Meteorol., 25, 38-52, 1987.

Granger Morgan, M., Adams, P. J. and Keith, D. W.: Elicitation of expert judgments of aerosol forcing, Clim. Change, 75, 195-214, 2006.

Hobbs, P. V. and Radke, L. W.: Airborne studies of the smoke from the Kuwait oil fires, Science, 256, 987-991, 1992.

Hansen, J., Sato, M., and Ruedy, R.: Radiative forcing and climate response, J. Geophys. Res., 102, 6831-6864, 1997.

Hatzianastassiou, N., Katsoulis, B. and Vardavas, I.: Sensitivity analysis of aerosol direct radiative forcings in the ultraviolet - visible wavelengths and consequences for the heat budget, Tellus, 56B, 368-381, 2004.

Hatzianastassiou, N., Matsoukas, C., Fotiadi, A., Stackhouse, P. W. Jr., Koepke, P., Drakakis, E., Pavlakis, K. G., Hatzidimitriou, D., and Vardavas, I.: Modelling the direct effect of aerosols in the solar near infrared on a planetary scale, Atmos. Chem. Phys. Discuss., 6, 9151-9185, 2006 ,

http://www.atmos-chem-phys-discuss.net/6/9151/2006/.

Hauser, A., Oesch, D., and Foppa, N.: Aerosol optical depth over land: Comparing AERONET, AVHRR and MODIS, Geophys. Res. Lett., 32, L17816, doi:10.1029/2005GL023579, 2005.

Haywood, J. M. and Boucher, O.: Estimates of the direct and indirect radiative forcing due to troposheric aerosols: a review, Rev. Geophys., 38, 513-543, 2000.

Heintzenberg, J. R., Charlson, R. J., Clarke, A. D., Liousse, C., Ramaswamy, V., Shine, K. P., and Wendisch, M.: Measurement and modeling of aerosol single scattering albedo: progress, problems and prespects, Contrib. Atmos. Phys., 70, 249-364, 1997.

30 Holben, B. N., Setzer, A., Eck, T. F., Pereira, A., and Slutsker, I.: Effect of dry season biomass burning on Amazon basin aerosol concentrations and optical properties, J. Geophys. Res., 101, 19465-19481, 1996.

Holben, B. N., Eck, T. F., Slutsker, I., Tanré, D., Buis, J. P., Setzer, A., Vermote, E., Reagan,

\section{Climatology of different aerosol types}

D. G. Kaskaoutis et al.

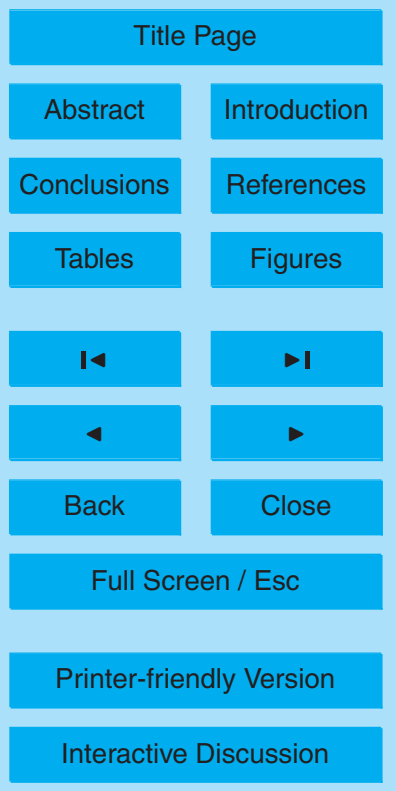


J. A., and Kaufman, Y. A.: AERONET-a federated instrument network and data achieve for aerosol characterization, Remote Sens. Environ., 66, 1-16, 1998.

Holben, B. N., Tanre, D., Smirnov, A., Eck, T. F., Slutsker, I., et al.: An emerging ground-based aerosol climatology: Aerosol optical depth from AERONET, J. Geophys. Res., 106, 12 06712 097, 2001.

IPCC.: Climatic change 2001, The Scientific Basis, in: The science of Climate Change, edited by: Houghton, J. T., Ding, Y., Griggs, D. G., et al., Cambridge University Press, Cambridge, UK. 2001.

Kaskaoutis, D. G. and Kambezidis, H. D.: Investigation on the wavelength dependence of the aerosol optical depth in the Athens area, Q. J. R. Meteorol. Soc., 132, 2217-2234, 2006.

Kaufman, Y. J., Setzer, A., Ward, D., Tanrè, D., Holben, B. N., Menzel, P., Pereira, M. C., and Ramussen, R.: Biomass burning airborne and spaceborne experiment in the Amazonas (BASE-A), J. Geophys. Res., 97, 14581-14599, 1992.

Kim, D. H., Sohn, B. J., Nakajima, T., Takamura, T., Choi, B. C., and Yoon, S. C.: Aerosol optical 15 properties over eastern Asia determined from ground-based sky radiation measurements, J. Geophys. Res., 109, D02209, doi:101029/2003JD003387, 2004.

Kinne, S. and Pueschel, R.: Aerosol radiative forcing for Asian continental outflow, Atmos. Envir., 35, 5019-5028, 2001.

Kristjánsson, J. E., Iversen, T., Kirkevåg A., Seland, $\varnothing$, and Debernard, J.: Response of the climate system to aerosol direct and indirect forcing: Role of cloud feedbacks, J. Geophys. Res., 110, D24206, doi:10.1029/2005JD006299, 2005.

Latha, M. K. and Badarinath, K. V. S.: Seasonal variations of black carbon aerosols and total aerosol mass concentrations over urban environment in India, Atmos. Envir. 39, 4129-4141, 2005.

Lau, K. M., Kim, M. K. and Kim, K. M.: Asian summer monsoon anomalies induced by direct forcing: The role of the Tibetan plateau, Climate Dyn., 26, 855-864, 2006.

Liu, M., Westphal, D. L., and Holt, T.: Numerical study of a low-level jet over complex terrain in southern Iran, Mon. Wea. Rev., 128, 1309-1327, 2000.

Masmoudi, M., Chaabane, M., Tanré, D., Gouloup, P., Blarel, L., and Elleuch, F.: Spatial and 30 temporal variability of aerosol: size distribution and optical properties, Atmos. Res., 66, 1-19, 2003.

Mather, J. H., Ackerman, T. P., Clements, W. E., Barnes, F. J., lley, M. D., Hatfield, L. D., and Reynolds, R. M.: An atmospheric radiation and cloud station in the tropical western Pacific,

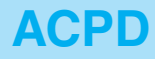

$7,6357-6411,2007$

\section{Climatology of different aerosol types}

D. G. Kaskaoutis et al.

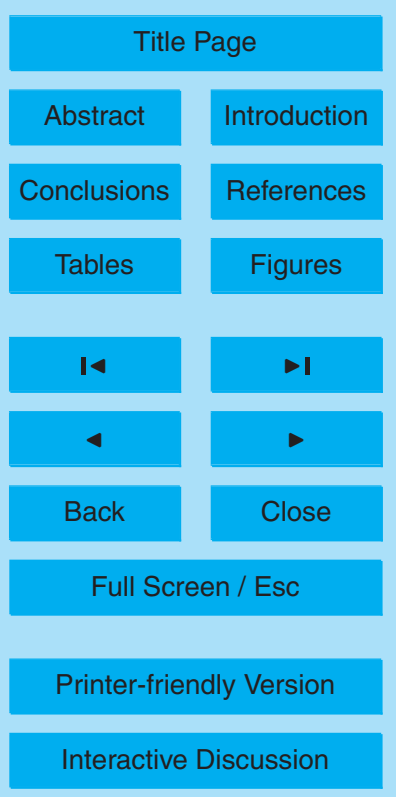


Bull. Am. Meteorol. Soc., 79, 627-642, 1998.

Mukai, S., Sano, I., Satoh, M., and Holben, B.N.: Aerosol properties and air pollutants over an urban area, Atmos. Res., 82, 643-651, 2006.

Ogunjobi, K. O., He, Z., Kim, K. W., and Kim, Y. J.: Aerosol optical depth during episodes

5 of Asian dust storms and biomass burning at Kwangju, South Korea, Atmos. Environ., 38, 1313-1323, 2004.

Otterman, J. T., Fraser, R. S., and Bahethi, O. P.: Characterization of tropospheric desert aerosols at solar wavelengths by multispectral radiometry from Landsat, J. Geophys. Res., 87, 1270-1278, 1982.

10 Pace, G., di Sarra, A., Meloni, D., Piacentino, S., and Chamard, P.: Aerosol optical properties at Lambeduca (Cenral Mediterranean). 1. Influence of transport and identification of different aerosol types, Atmos. Chem. Phys., 6, 697-713, 2006, http://www.atmos-chem-phys.net/6/697/2006/.

Porter, J. N. and Clarke, A. D.: Aerosol size distribution models based on in situ measurements, 15 J. Geophys. Res., 102, 6035-6045, 1997.

Ramachandran, S.: Spectral aerosol optical characteristics during the northeast monsoon over the Arabian Sea and the tropical Indian Ocean: 1 Aerosol optical depth and their variabilities, J. Geophys. Res., 109, D19208, doi:10.1029/20003JD004476, 2004.

Reid, J. S. and Hobbs, P. V.: Physical and optical properties of smoke from individual biomass fires in Brazil, J. Geophys. Res., 103, 32 013-32 031, 1998.

Reid, J. S., Hobbs, P. V., Ferek, R. J., Blake, D. R., Martins, J. V., Dunlap, M. R., and Liousse, C.: Physical, chemical and optical properties of regional hazes dominated by smoke in Brazil, J. Geophys. Res., 103, 32 059-32 080, 1998.

Reid, J. S., Eck, T. F., Christopher, S. A., Hobbs, P. V., and Holben, B. N.: Use of the Ångström exponent to estimate the variability of optical and physical properties of aging smoke particles in Brazil, J. Geophys. Res., 104(D22), 27 473-27 489, 1999.

Remer, L. A. and Kaufman, Y. J.: Aerosol direct radiative effect at the top of the atmosphere over cloud free ocean derived from four years of MODIS data, Atmos. Chem. Phys., 6, 237253, 2006,

$30 \quad$ http://www.atmos-chem-phys.net/6/237/2006/.

Remer, L. A., Kaufman, Y., Holben, B. N., Thompson, A. M., and McNamara, D. P.: Biomass burning aerosol size distribution and modeled optical properties, J. Geophys. Res., 103, 31 879-31 891, 1998.

\section{Climatology of different aerosol types}

D. G. Kaskaoutis et al.

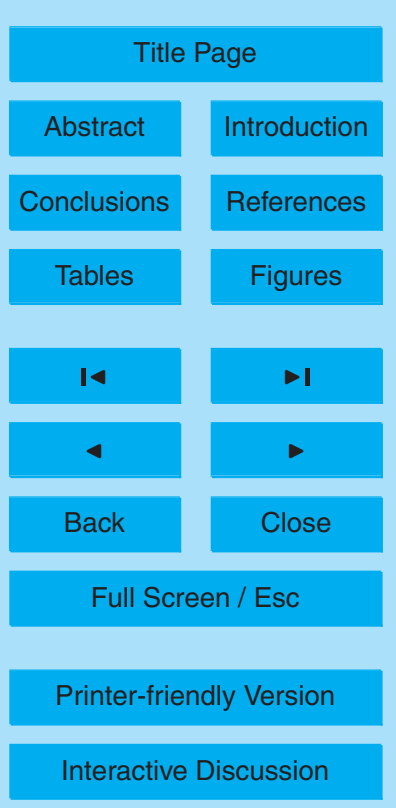


Satheesh, S. K. and Krishna Moorthy, K.: Radiative effects of natural aerosols: A review, Atmos. Envir., 35, 2089-2110, 2005.

Schuster, G. L., Dubovik, O., and Holben, B. N.: Ångström exponent and bimodal aerosol size distributions, J. Geophys. Res., 111, D07207, doi:101029/2005JD006328, 2006.

5 Seinfeld, J. H. and Pandis, S. N.: Atmospheric Chemistry and Physics: From Air Pollution to Climate Change, John Wiley, New York, p. 1326, 1997.

Shifrin, K. S.: Simple relationships for the Ångström parameter of disperse systems, Appl. Opt., 34, 4480-4485, 1995.

Smirnov, A., Holben, B. N., Slutsker, I., Welton, E. J., and Formenti, P.: Optical properties of Saharan dust during ACE 2, J. Geophys. Res., 103, 28 079-28 092, 1998.

Smirnov, A., Holben, B. N., Savoie, D., Prospero, J.M., Kaufman, Y.J., Tanrè, D., Eck, T. F., and Slutsker, I.: Relationship between column aerosol optical thickness and in situ ground based dust concentrations over Barbados, Geophys. Res. Lett., 27, 1643-1646, 2000 a.

Smirnov, A., Holben, B. N., Eck, T. F., Dubovik, O., and Slutsker, I.: Cloud screening and quality 15 control algorithms for the AERONET data base, Remote Sens. Env., 73, 337-349, 2000b.

Smirnov, A., Dubovik, O., O'Neil, N. T., Remer, L. A., Eck, T. F., Slutsker, I., and Savoie, D.: Measurements of atmospheric optical parameters on U.S. Atlantic coast sites, ships and Bermuda during TARRFOX, J. Geophys. Res., 105, 9887-9901, 2000c.

Smirnov, A., Holben, B. N., Dubovic, O., O'Neil, N. T., Eck, T. F., Westphal, D.L., Goroth, A. K., Pietras, C., and Slutsker, I.: Atmospheric aerosol optical properties in the Persian Gulf, J. Atmos. Sci., 59, 620-634, 2002a.

Smirnov, A., Holben, B. N., Kaufman, Y. J., Dubovic, O., Eck, T. F., Slutsker, I., Pietras, C., and Halthore, R. N.: Optical properties of atmospheric aerosol in Maritime Environments, J. Atmos. Sci., 59, 501-523, 2002b.

Smirnov, A., Holben, B. N., Eck, T. F., Slutsker, I., Chatenet, B., and Pinker, R. T.: Diurnal variability of aerosol optical depth observed at AERONET (Aerosol Robotic Network) sites, Geophys. Res. Lett., 29, 2115 doi:10.1029/2002GL016305, 2002c.

Smirnov, A., Holben, B. N., Dubovic, O., Fruin, R., Eck, T. F., Slutsker, I.: Maritime component in aerosol optical models derived from aerosol robotic network data, J. Geophys. Res., 108(D1), 4033, 4033, 2003.

Sokolik, I. N. and Toon, O. B.: Incorporation of mineralogical composition into models of the radiative properties of mineral aerosol from UV to IR wavelengths, J. Geophys. Res., 104, 9423-9444, 1999.

\section{Climatology of different aerosol types}

D. G. Kaskaoutis et al.

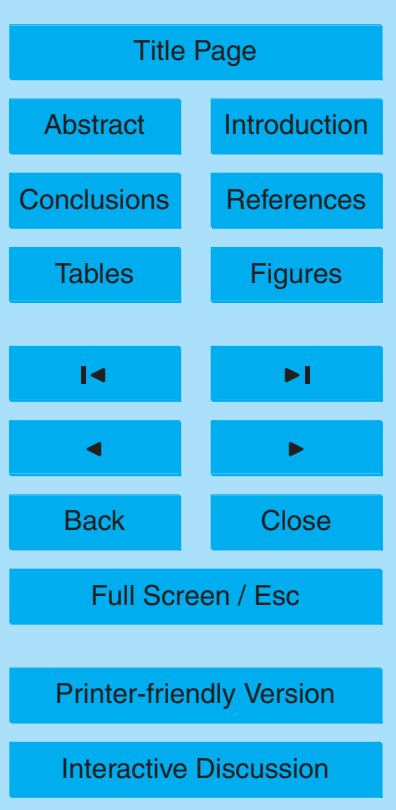


Xin, J., Wang. S., Wang, Y., Yuan, J., Zhang, W., and Sun, Y.: Optical properties and size distribution of dust aerosols over the Tengger Desert in Northern China, Atmos. Environ., 39, 5971-5978, 2005.

Yu, H., Kaufman, Y. J., Chin, M., Feingold, G., Remer, L. A., Anderson, T. L., Balkanski, Y., 5 Bellouin, N., Boucher, O., Christopher, S., DeCola, P., Kahn, R., Koch, D., Loeb, N., Reddy, M. S., Schulz, M., Takemura, T. and Zhou, M.: A review of measurement-based assessment of aerosol direct radiative effect and forcing, Atmos. Chem. Phys., 6, 613-666, 2006, http://www.atmos-chem-phys.net/6/613/2006/.

Zhao, T. X.-P., Laszlo, I., Minnis, P., and Remer, L.: Comparison and analysis of two aerosol retrievals over the ocean in the Terra/Clouds and the Earth's Radiant Energy System-Moderate Resolution Imaging Spectroradiometer single scanner footprint data: 1. Global evaluation, J. Geophys. Res., 110, D21208, doi:10.1029/2005JD005851, 2005.

\section{ACPD}

7, 6357-6411, 2007

Climatology of different aerosol types

D. G. Kaskaoutis et al.

Title Page

Abstract

Introduction

Conclusions

References

Tables

Figures

14

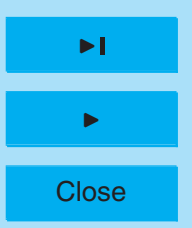

Back

Full Screen / Esc

Printer-friendly Version

Interactive Discussion 


\section{ACPD}

$7,6357-6411,2007$

\section{Climatology of different aerosol types}

Table 1. Period of measurements of aerosol optical properties at four selected AERONET stations and number of daily mean data in each site per season. In parentheses they are also given the percentages of the total number of measurements to which correspond the seasonal data.

\begin{tabular}{lllllll}
\hline Location & $\begin{array}{l}\text { Period of } \\
\text { measurements }\end{array}$ & Total & Winter & Spring & Summer & Autumn \\
\hline Alta Floresta & Jan/02-Dec/04 & 561 & $90(16 \%)$ & $124(22 \%)$ & $181(32 \%)$ & $166(30 \%)$ \\
Ispra & Jan/02-Mar/04 & 653 & $148(23 \%)$ & $165(25 \%)$ & $217(33 \%)$ & $123(19 \%)$ \\
Nauru & Mar/02-May/04 & 363 & $78(21 \%)$ & $131(36 \%)$ & $79(22 \%)$ & $75(21 \%)$ \\
Solar Village & Jan/02-Aug/04 & 792 & $169(21 \%)$ & $242(31 \%)$ & $209(26 \%)$ & $172(22 \%)$ \\
\hline
\end{tabular}

D. G. Kaskaoutis et al.

Title Page

Abstract Introduction

Conclusions References

Tables

Figures

14

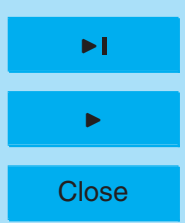

Back 
Table 2. Seasonal frequency of occurrence (\%) of different aerosol types identified at the four representative AERONET stations of Alta Floresta, Ispra, Nauru and Solar Village, for the 3-year period 2002-2004. The frequencies are given for each season (winter, DecemberJanuary-February), (spring, March-April-May), (summer, June-July-August) and (autumn, September-October-November) as well as on a year basis.

\begin{tabular}{llllll}
\hline Site & Season & $\begin{array}{l}\text { Biomass/ } \\
\text { Urban }\end{array}$ & Clean Maritime & $\begin{array}{l}\text { Desert } \\
\text { dust }\end{array}$ & $\begin{array}{l}\text { Mixed } \\
\text { type }\end{array}$ \\
\hline \multirow{5}{*}{ Alta Floresta } & Year & 41.8 & 6.0 & 0.7 & 51.5 \\
& Winter & 11.3 & 7.7 & 3.3 & 77.7 \\
& Spring & 8.8 & 15.3 & 1.6 & 75.3 \\
& Summer & 59.1 & 4.4 & 0 & 36.5 \\
& Autumn & 63.8 & 0 & 0 & 36.2 \\
& & & & & \\
\multirow{5}{*}{ Ispra } & Year & 47.2 & 13.7 & 0.6 & 38.5 \\
& Winter & 31.8 & 26.2 & 2 & 39.8 \\
& Spring & 33.9 & 5.5 & 1.2 & 59.4 \\
& Summer & 64.5 & 8.3 & 0.5 & 26.7 \\
& Autumn & 52.8 & 17 & 0.0 & 30.2 \\
\multirow{5}{*}{ Nauru } & Year & 0 & & & \\
& Winter & 0 & 56.7 & 3.0 & 40.3 \\
& Spring & 0 & 65.4 & 3.8 & 30.8 \\
& Summer & 0 & 52.4 & 4.6 & 43.0 \\
& Autumn & 0 & 51.9 & 1.3 & 46.8 \\
& & 60.3 & 1.4 & 38.3 \\
\multirow{5}{*}{ Solar Village } & Year & 0 & & & \\
& Winter & 0 & 3.7 & 46.6 & 49.7 \\
& Spring & 0 & 14.8 & 30.2 & 55 \\
& Summer & 0 & 0 & 79.3 & 20.7 \\
& Autumn & 0 & 0 & 47.6 & 52.4 \\
\hline
\end{tabular}




\section{ACPD}

7, 6357-6411, 2007

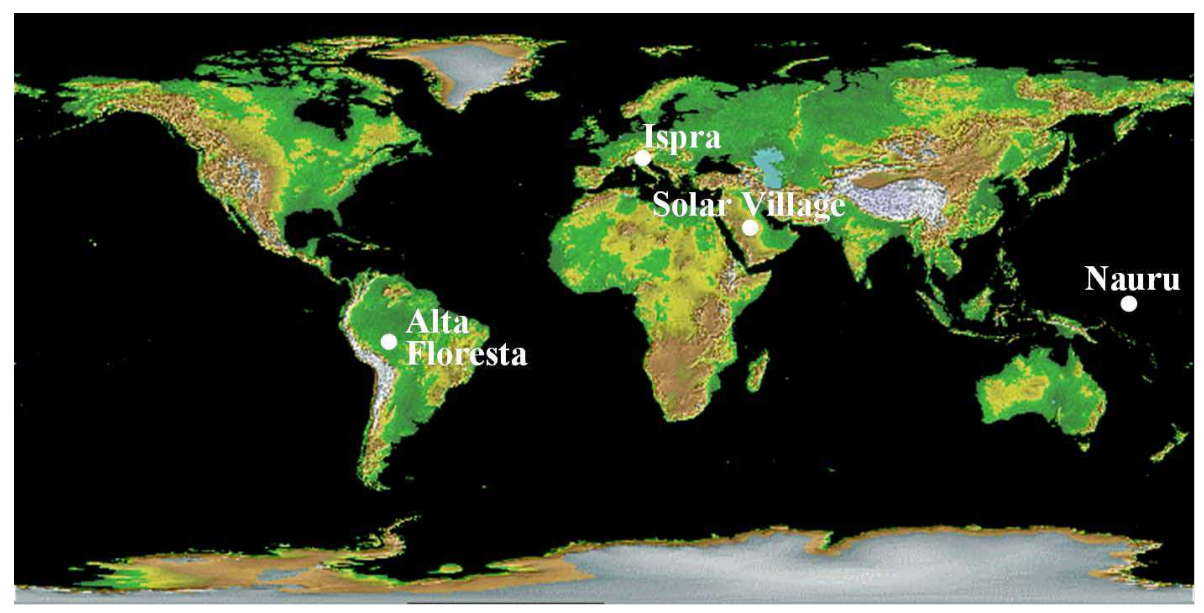

\section{Climatology of different aerosol types}

D. G. Kaskaoutis et al.

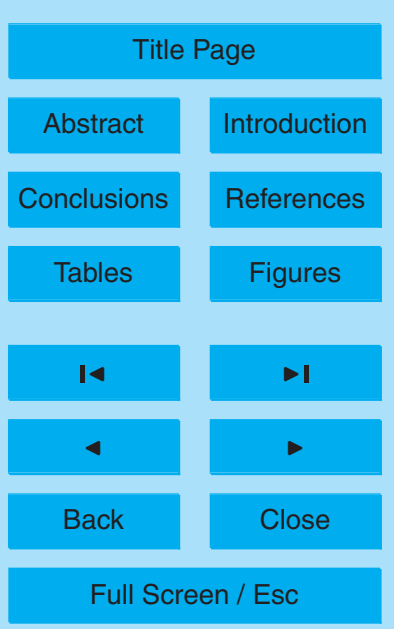

Printer-friendly Version

Interactive Discussion 


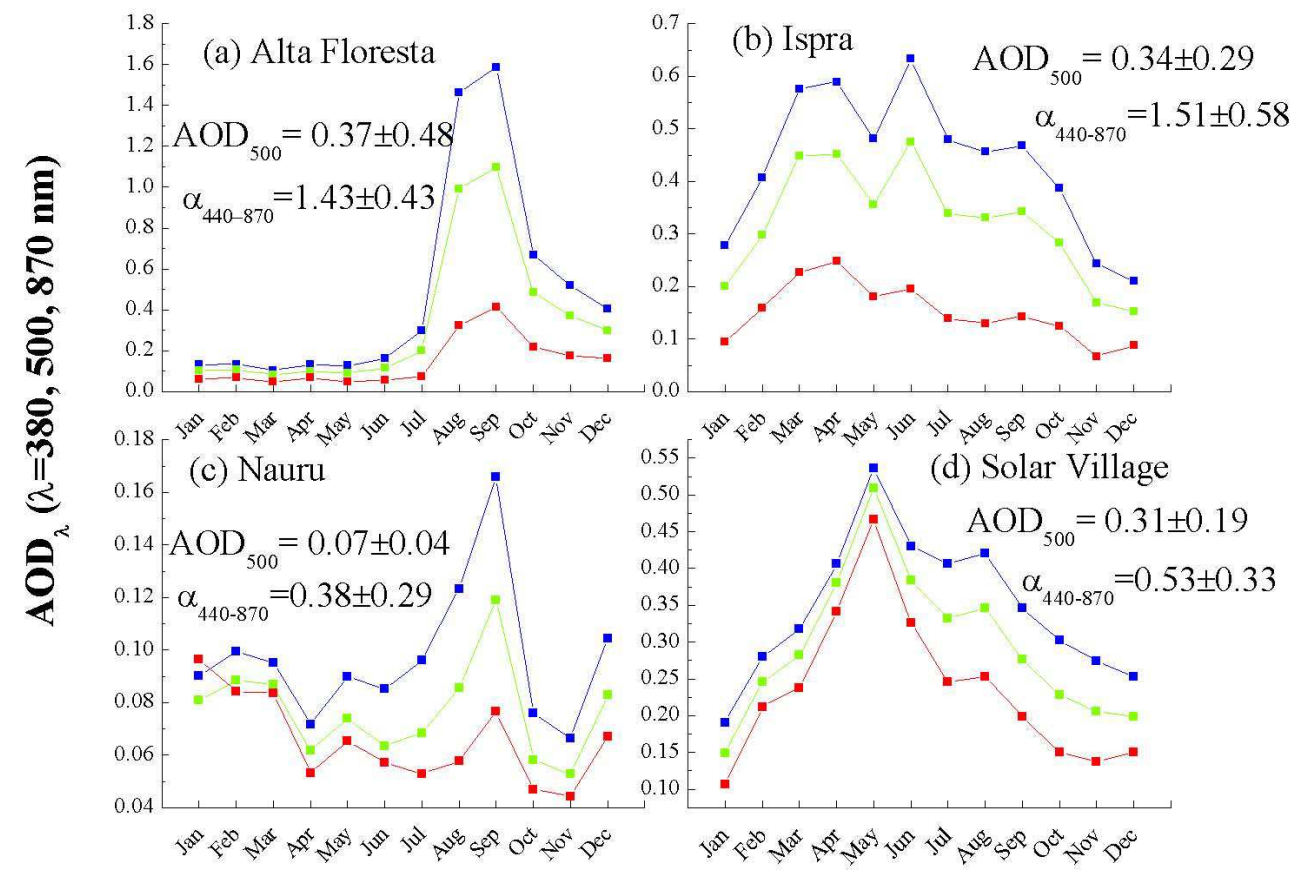

Month

Fig. 2. Intra-annual variation of aerosol optical depth (AOD) for the AERONET sites: (a) Alta Floresta, (b) Ispra, (c) Nauru, and (d) Solar Village, at $380 \mathrm{~nm}$ (blue lines), $500 \mathrm{~nm}$ (green lines), $675 \mathrm{~nm}$ (yellow lines) and $870 \mathrm{~nm}$ (red lines). The computed annual mean values of AOD at $500 \mathrm{~nm}\left(\mathrm{AOD}_{500}\right)$ and Angstrom parameter $\left(\alpha_{440-870}\right)$ are also given for each station.

\section{ACPD}

$7,6357-6411,2007$

Climatology of different aerosol types

D. G. Kaskaoutis et al.

Title Page

Abstract

Introduction

Conclusions

References

Tables

Figures

14

I

4

Back

Close

Full Screen / Esc

Printer-friendly Version

Interactive Discussion 

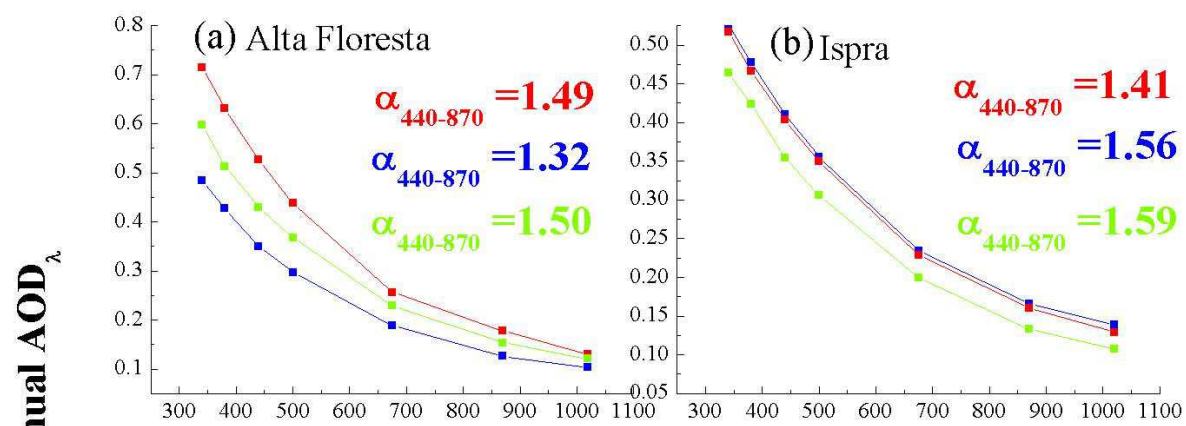

\section{ACPD}

$7,6357-6411,2007$

\section{Climatology of different aerosol types}

D. G. Kaskaoutis et al.
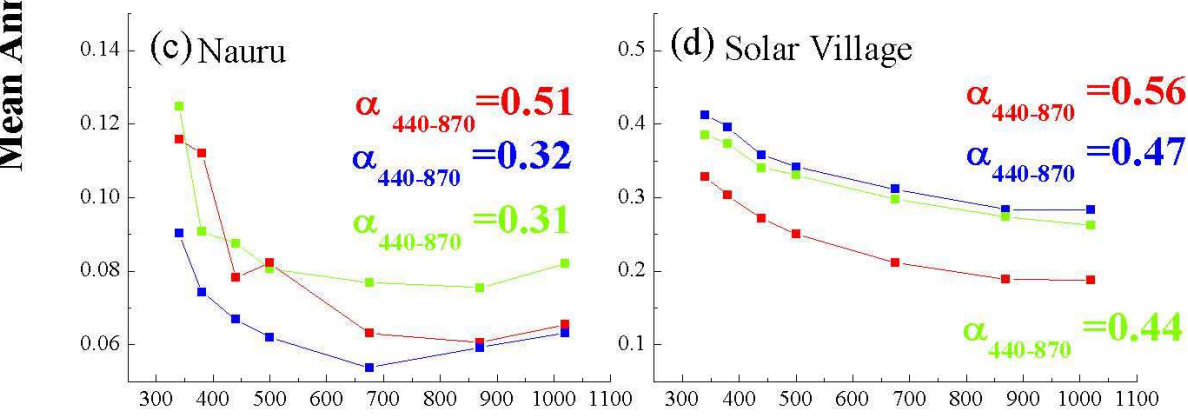

Title Page

\section{Wavelength $(\mathrm{nm})$}

Fig. 3. Spectral variation of the mean annual AOD (2002 in red, 2003 in blue, 2004 in green) in the four selected AERONET stations: (a) Alta Floresta, (b) Ispra, (c) Nauru, and (d) Solar Village. The computed annual mean values of Angstrom parameter $\left(\alpha_{440-870}\right)$ are also given for each station.

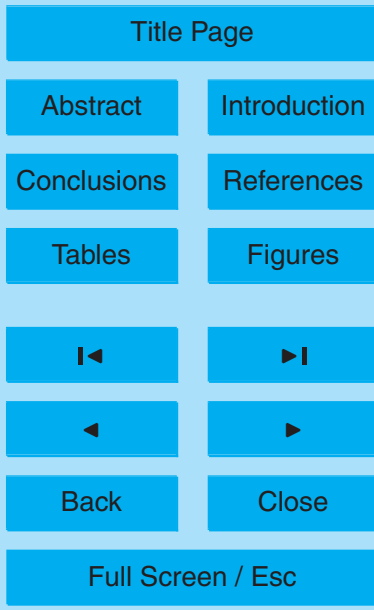

Printer-friendly Version

Interactive Discussion 

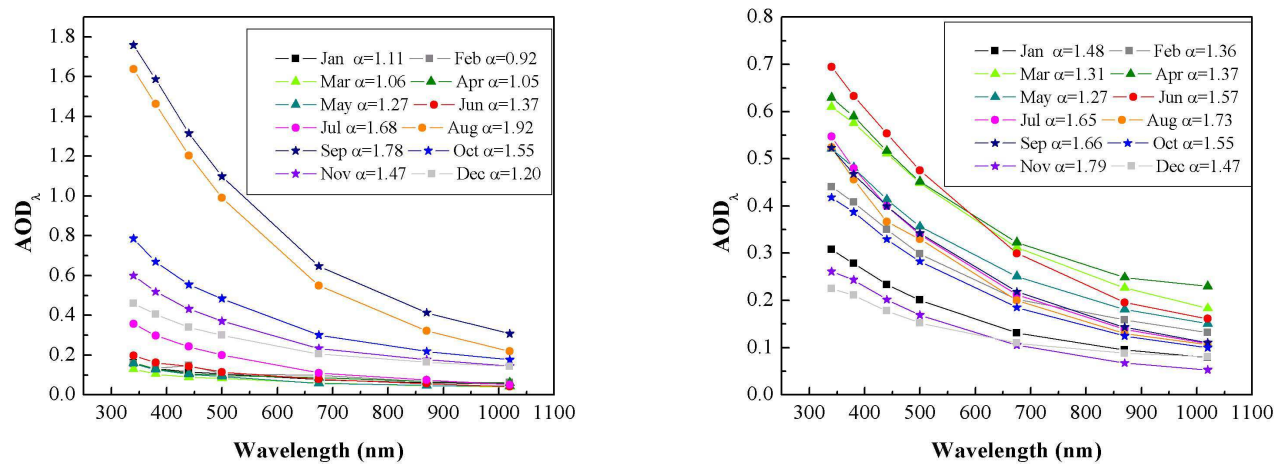

ACPD

\section{$7,6357-6411,2007$}

\section{Climatology of different aerosol types}

D. G. Kaskaoutis et al.
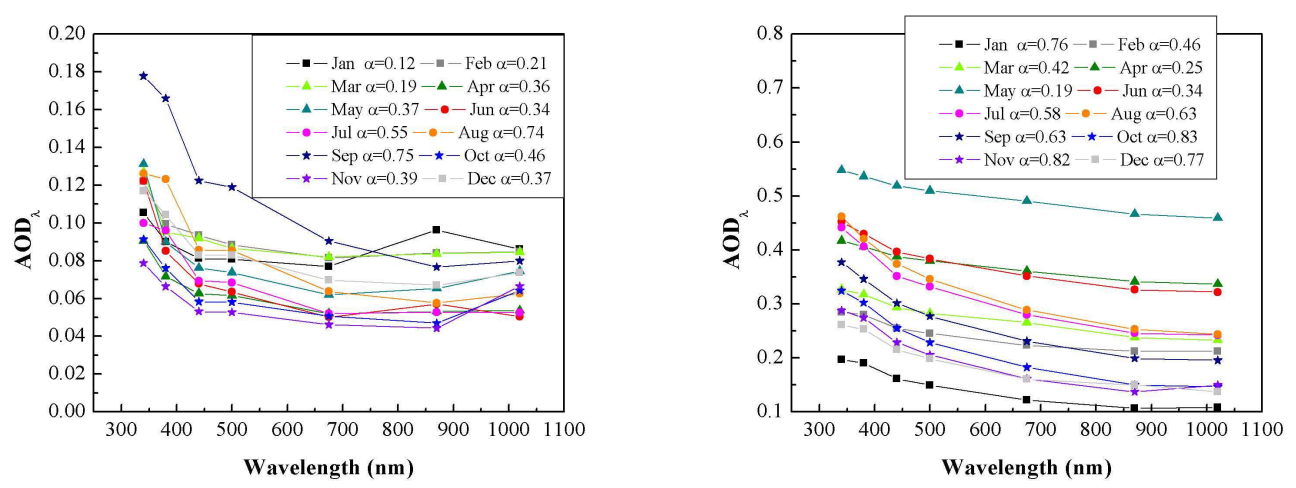

Title Page

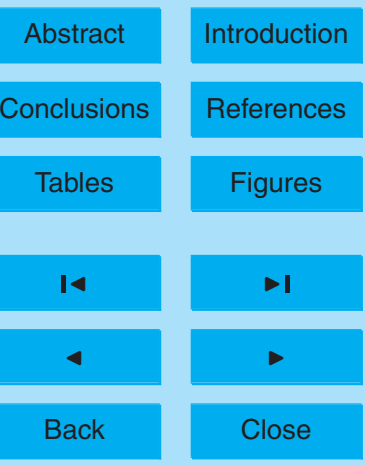

Full Screen / Esc

Fig. 4. Spectral variation of 3-year (2002-2004) averages of mean monthly AOD in the four selected AERONET stations: (a) Alta Floresta, (b) Ispra, (c) Nauru, and (d) Solar Village. The computed monthly mean values of Angstrom parameter $\left(\alpha_{440-870}\right)$ are also given for each

Printer-friendly Version station. 


\section{ACPD}

\section{$7,6357-6411,2007$}

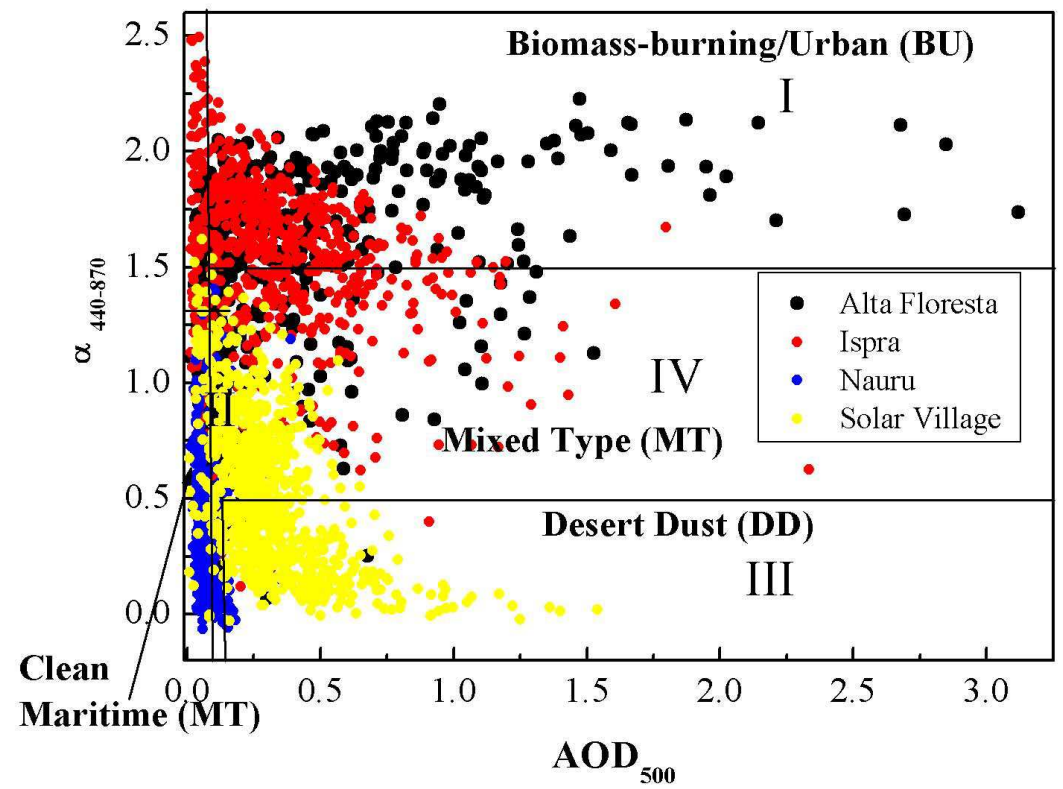

\section{Climatology of different aerosol types}

D. G. Kaskaoutis et al.

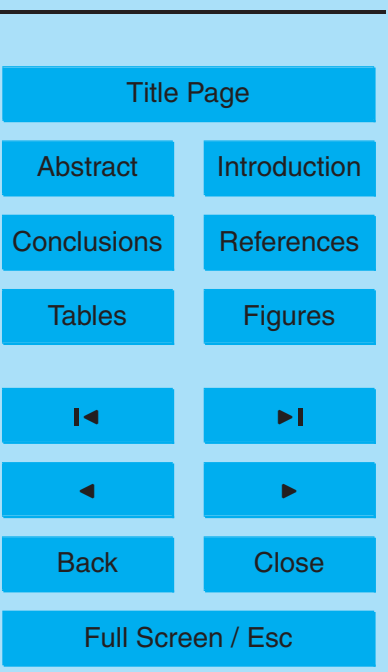

Fig. 5. Scatterplot of Angstrom parameter $\left(\alpha_{440-870}\right)$ versus aerosol optical depth at $500 \mathrm{~nm}$ Full Screen / Esc $\left(A D_{500}\right)$ for the AERONET sites: Alta Floresta, Ispra, Nauru, and Solar Village. The discriminated different aerosol types: biomass burning-urban (BU, type I), clean maritime (CM, type II), desert dust (DD, type III) and mixed type (MT, type IV) are shown for each station. 


\section{ACPD}

\section{$7,6357-6411,2007$}

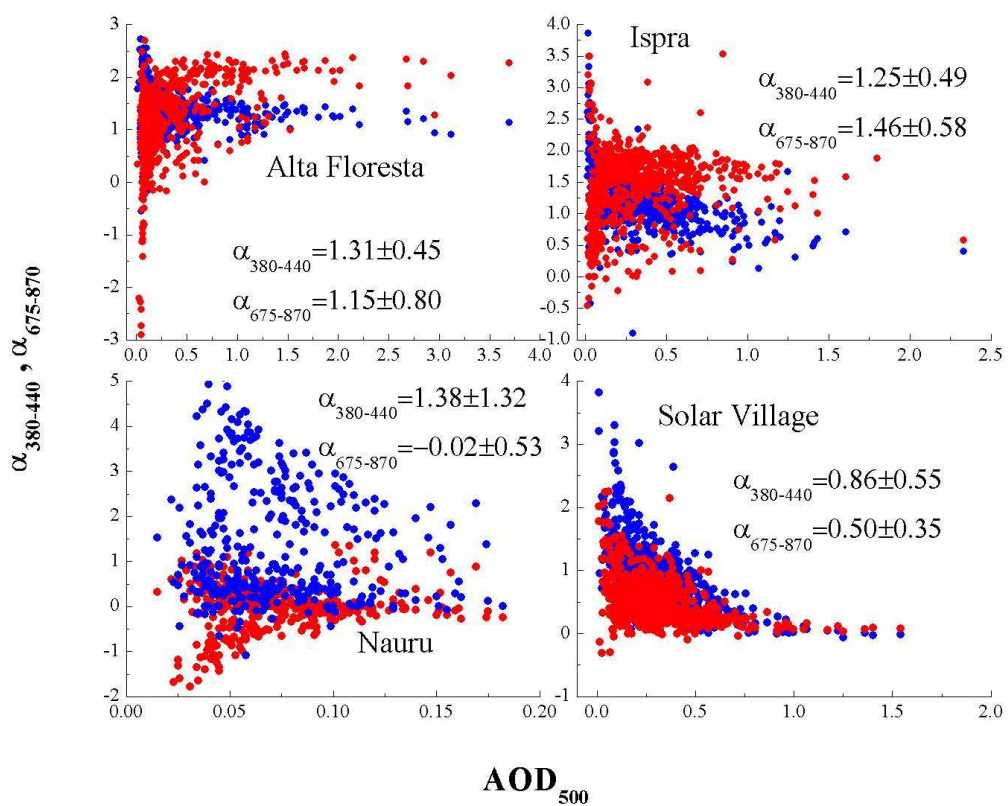

\section{Climatology of different aerosol types}

D. G. Kaskaoutis et al.

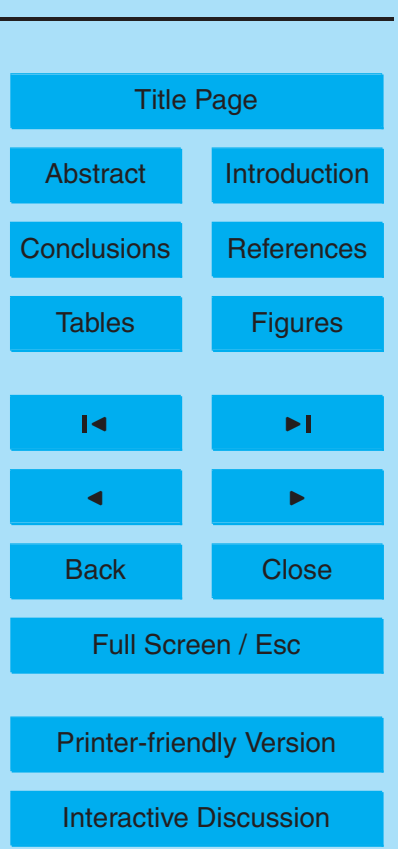

Fig. 6. Scatterplot of Angstrom parameter $(\alpha)$ versus aerosol optical depth at $500 \mathrm{~nm}\left(\mathrm{AOD}_{500}\right)$ for the AERONET sites: (a) Alta Floresta, (b) Ispra, (c) Nauru, and (d) Solar Village. The scatterplot for $\alpha_{380-440}$ (blue points) and $\alpha_{675-870}$ (red points) are given for each station. 

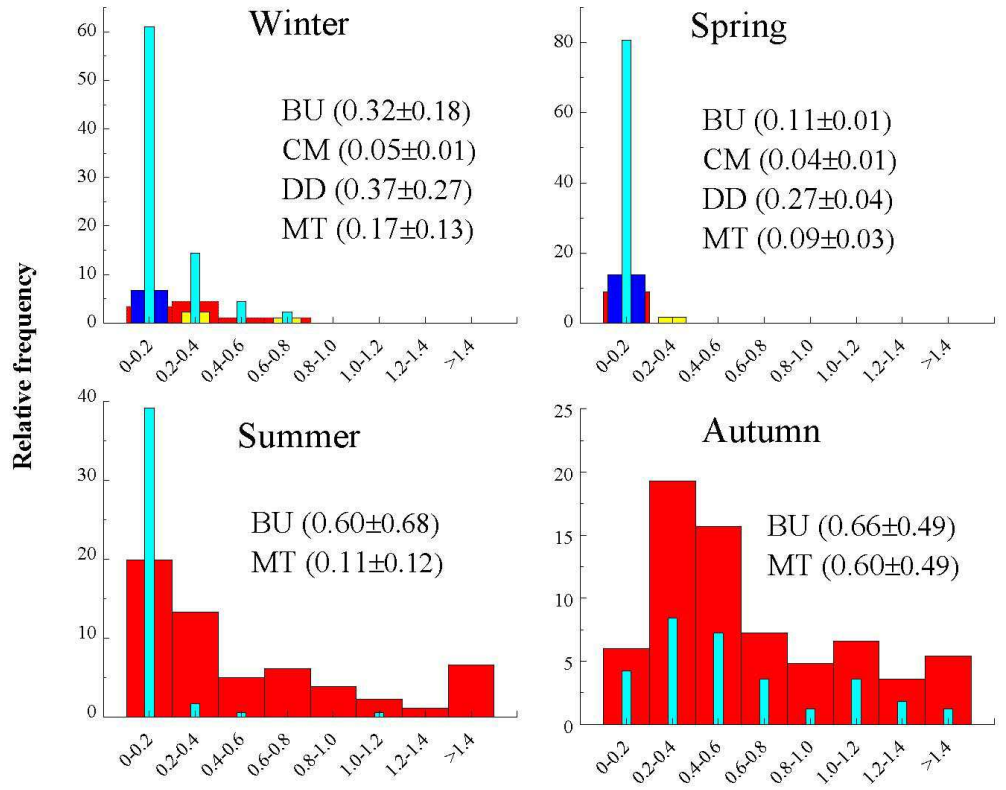

\section{Climatology of different aerosol types}

D. G. Kaskaoutis et al.

Fig. 7. Seasonal relative frequency of occurrence of different aerosol types (BU in red, CM in blue, DD in yellow and MT in cyan) identified at the Alta Floresta AERONET station for the 3-year period 2002-2004 during (a) winter (December-January-February), (b) spring (MarchApril-May), (c) summer (June-July-August) and (d) autumn (September-October-November). The frequency of occurrence is given for each interval of $A O D_{500}$, while seasonal mean $A O D_{500}$ values are also given for each aerosol type.

Title Page

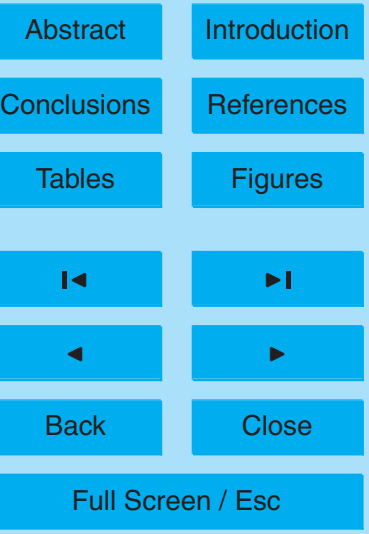

Printer-friendly Version

Interactive Discussion 


\section{ACPD}

$7,6357-6411,2007$
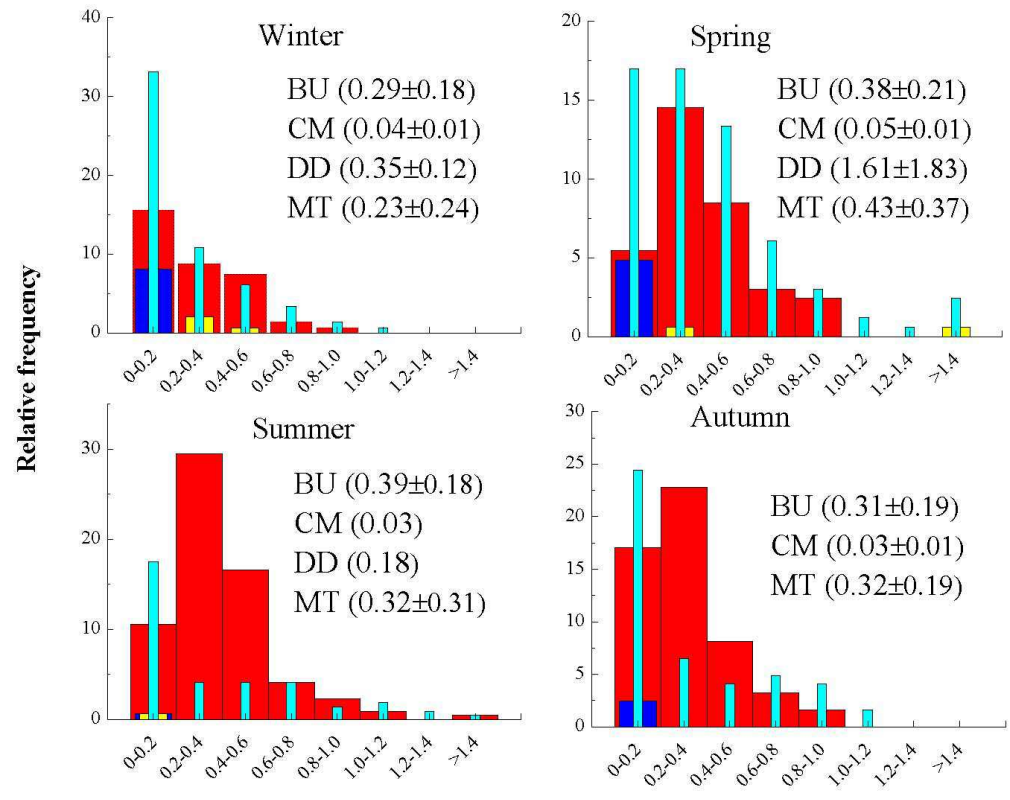

\section{Climatology of different aerosol types}

D. G. Kaskaoutis et al.

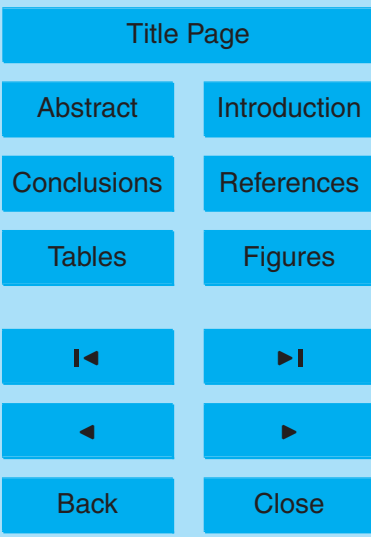

Full Screen / Esc

Fig. 8. As in Fig. 6, but for the Ispra AERONET station.

Printer-friendly Version

Interactive Discussion 


\section{ACPD}

7, 6357-6411, 2007
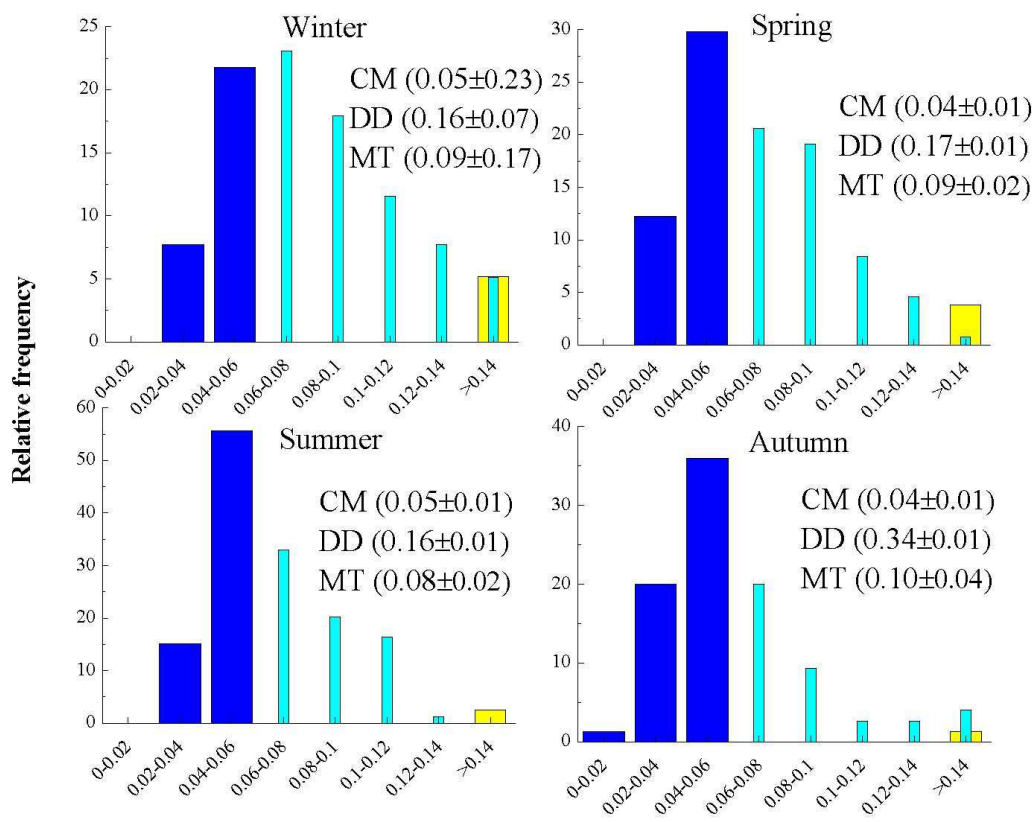

\section{Climatology of different aerosol types}

D. G. Kaskaoutis et al.

Title Page

Abstract

Introduction

Conclusions

References

Tables

Figures

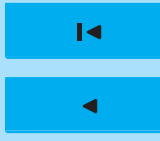

Back

Close

Full Screen / Esc

Printer-friendly Version

Interactive Discussion 


\section{ACPD}

$7,6357-6411,2007$
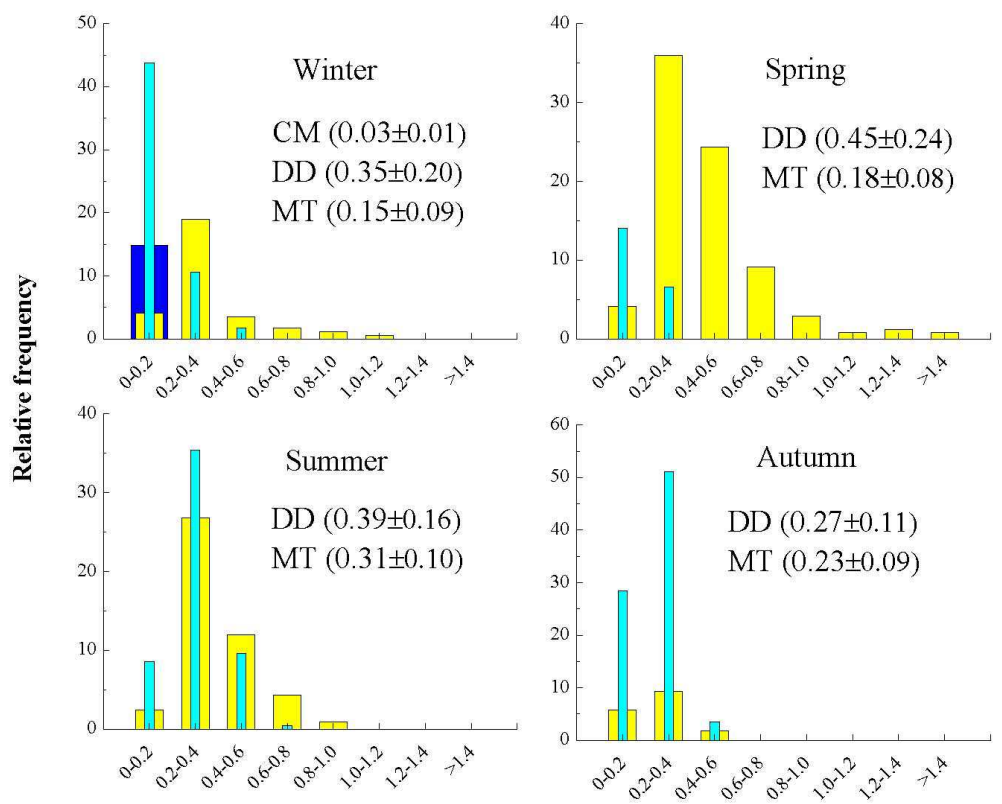

\section{Climatology of different aerosol types}

D. G. Kaskaoutis et al.

Title Page

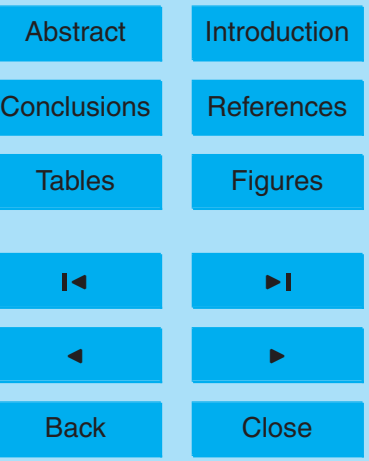

Full Screen / Esc

Fig. 10. As in Fig. 6, but for the Solar Village AERONET station.

Printer-friendly Version

Interactive Discussion 


\section{ACPD}
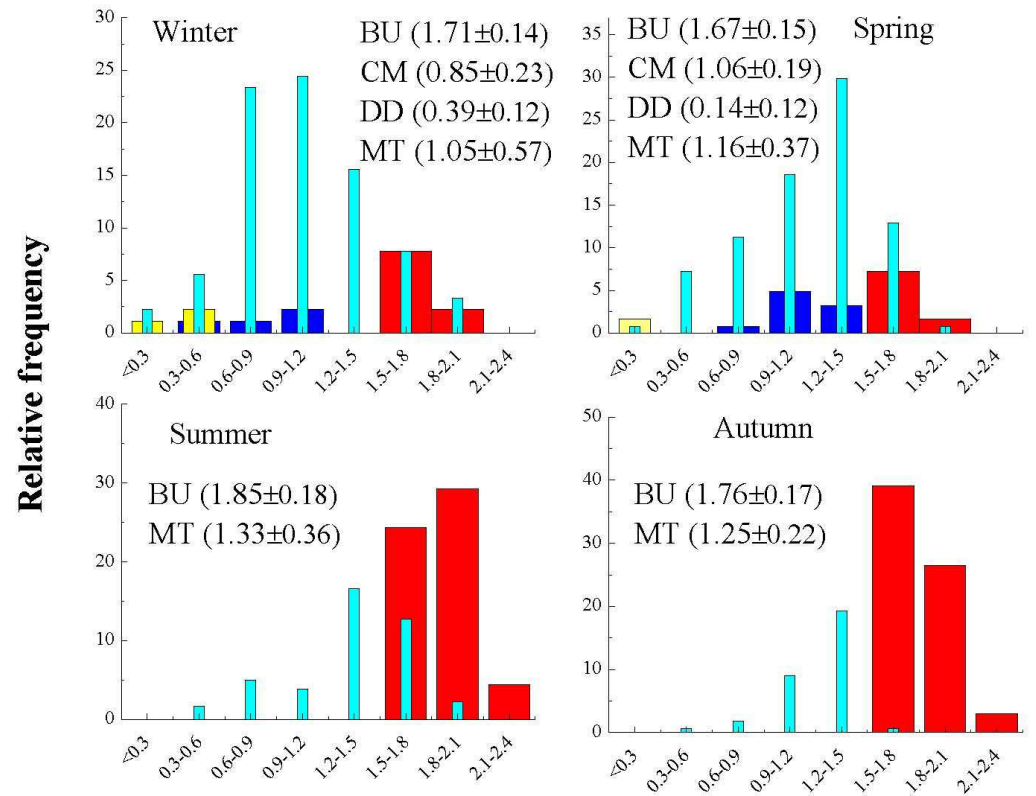

Climatology of different aerosol types

D. G. Kaskaoutis et al.

Fig. 11. Seasonal relative frequency of occurrence of different aerosol types (BU in red, $C M$ in blue, DD in yellow and MT in cyan) identified at the Alta Floresta AERONET station for the 3-year period 2002-2004 during (a) winter (December-January-February), (b) spring (MarchApril-May), (c) summer (June-July-August) and (d) autumn (September-October-November). The frequency of occurrence is given for each interval of $\alpha_{440-870}$, while seasonal mean $\alpha_{440-870}$ values are also given for each aerosol type.

Title Page

Abstract Introduction

Conclusions References

Tables

Figures

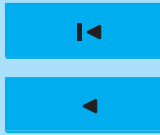

-

\section{Back}

Close
Printer-friendly Version

Interactive Discussion 


\section{ACPD}

7, 6357-6411, 2007
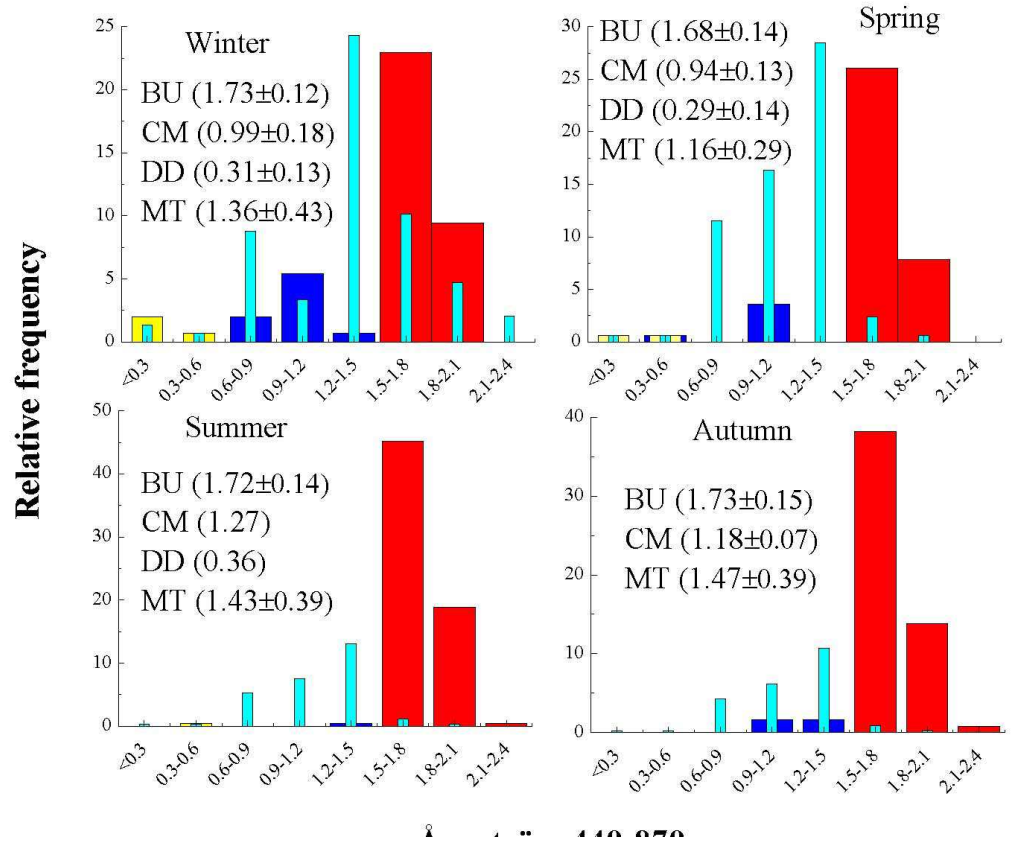

\section{Climatology of different aerosol types}

D. G. Kaskaoutis et al.

Title Page

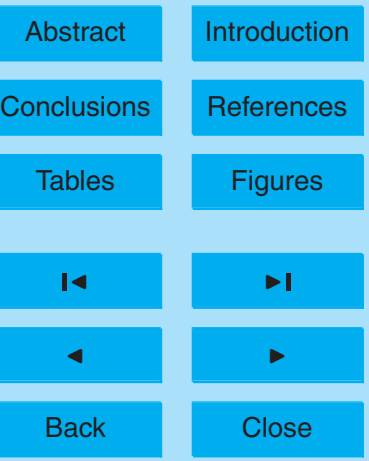

Full Screen / Esc

Fig. 12. As in Fig. 10, but for the Ispra AERONET station.

Printer-friendly Version

Interactive Discussion 


\section{ACPD}

7, 6357-6411, 2007

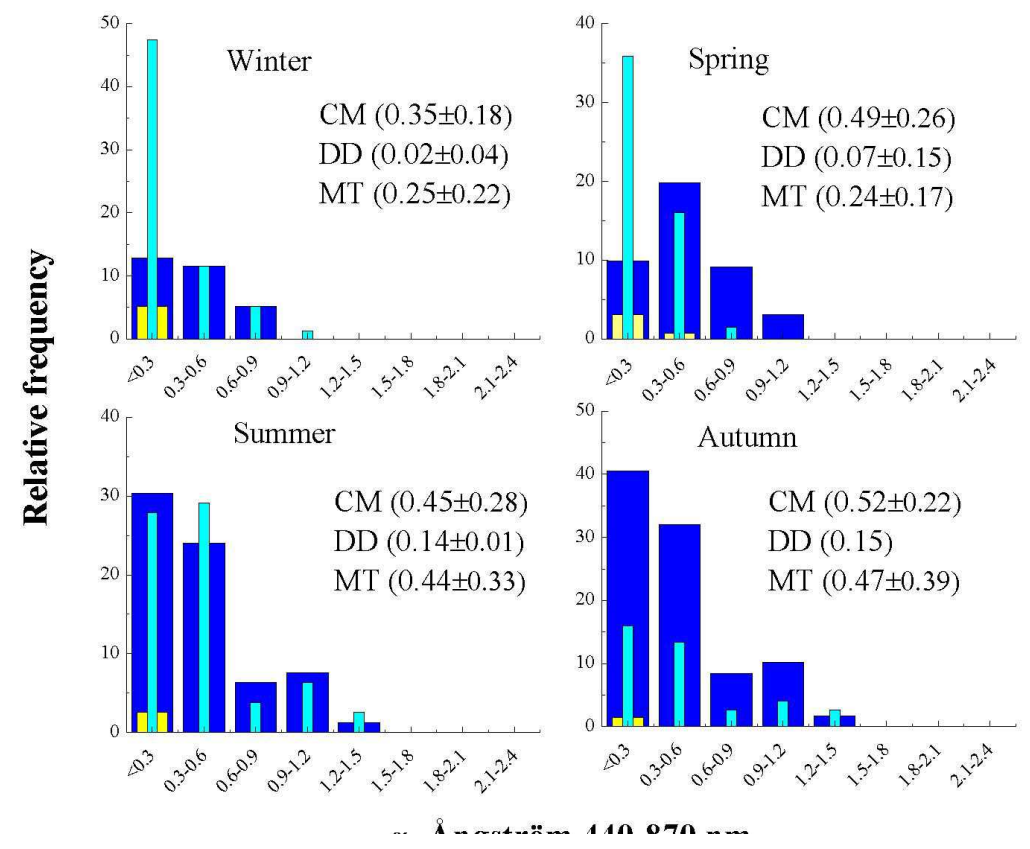

\section{Climatology of different aerosol types}

D. G. Kaskaoutis et al.

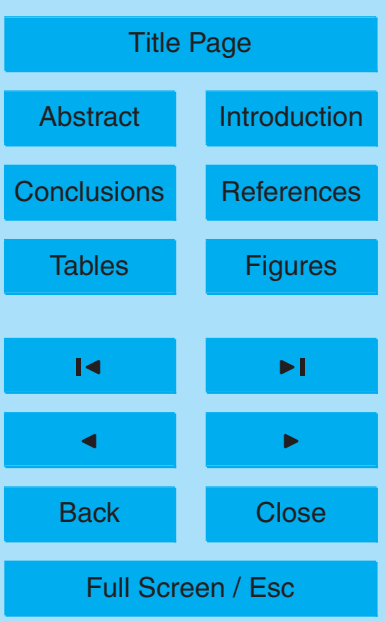

Fig. 13. As in Fig. 10, but for the Nauru AERONET station. 


\section{ACPD}

$7,6357-6411,2007$

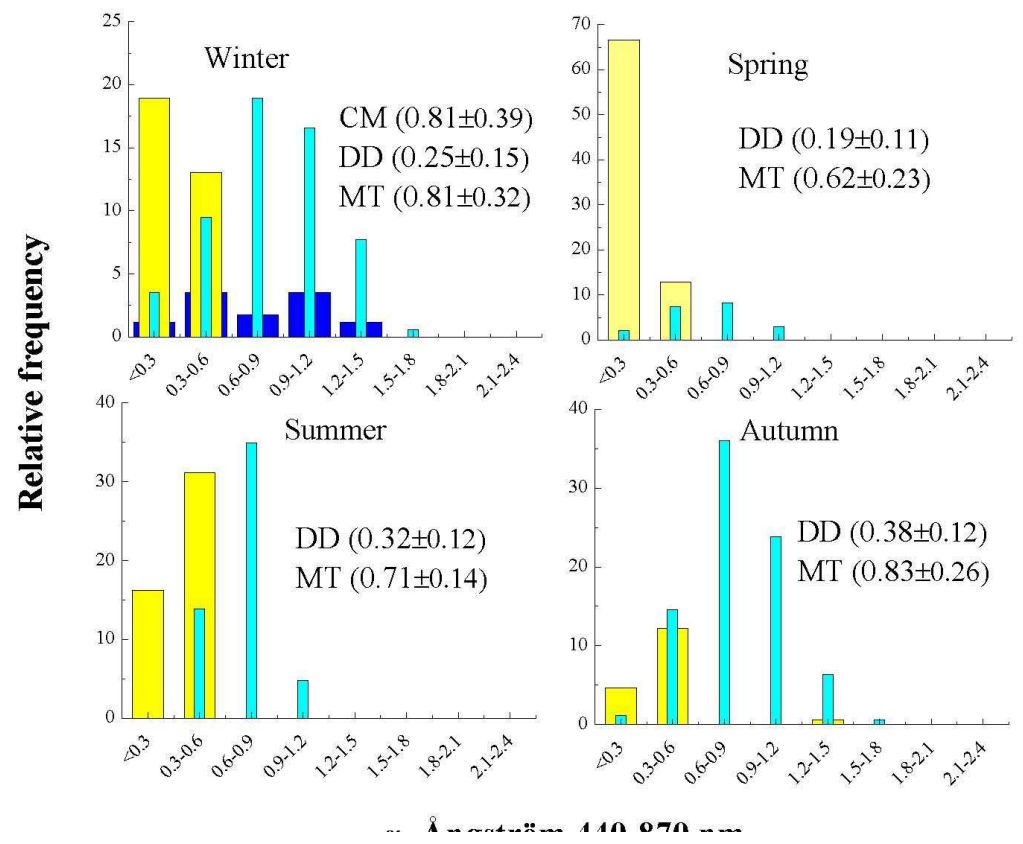

\section{Climatology of different aerosol types}

D. G. Kaskaoutis et al.

Title Page

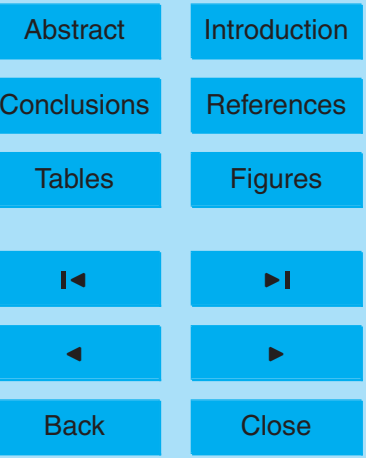

Full Screen / Esc

Fig. 14. As in Fig. 10, but for the Solar Village AERONET station.

Printer-friendly Version

Interactive Discussion 